\title{
Changes in inland lakes on the Tibetan Plateau over the past 40 years
}

\author{
FANG Yue ${ }^{1,2,3},{ }^{*}$ CHENG Weiming ${ }^{2,4},{ }^{*}$ ZHANG Yichi ${ }^{5}$, WANG Nan ${ }^{2,3}$, \\ ZHAO Shangmin ${ }^{6}$, ZHOU Chenghu ${ }^{1,2}$, CHEN Xi $^{1}$, BAO Anming ${ }^{1}$
}

1. Xinjiang Institute of Ecology and Geography, CAS, Urumqi 830011, China;

2. State Key Laboratory of Resources and Environmental Information System, Institute of Geographic Sciences and Natural Resources Research, CAS, Beijing 100101, China;

3. University of Chinese Academy of Sciences, Beijing 100049, China;

4. Jiangsu Center for Collaborative Innovation in Geographical Information Resource Development and Application, Nanjing 210023, China;

5. Key Laboratory of Water Cycle and Related Land Surface Processes, Institute of Geographic Sciences and Natural Resources Research, CAS, Beijing 100101, China;

6. Department of Surveying and Mapping, College of Mining Technology, Taiyuan University of Technology, Taiyuan 030024, China

\begin{abstract}
Inland lakes and alpine glaciers are important water resources on the Tibetan Plateau. Understanding their variation is crucial for accurate evaluation and prediction of changes in water supply and for retrieval and analysis of climatic information. Data from previous research on 35 alpine lakes on the Tibetan Plateau were used to investigate changes in lake water level and area. In terms of temporal changes, the area of the 35 alpine lakes could be divided into five groups: rising, falling-rising, rising-falling, fluctuating, and falling. In terms of spatial changes, the area of alpine lakes in the Himalayan Mountains, the Karakoram Mountains, and the Qaidam Basin tended to decrease; the area of lakes in the Naqu region and the Kunlun Mountains increased; and the area of lakes in the Hoh Xil region and Qilian Mountains fluctuated. Changes in lake water level and area were correlated with regional changes in climate. Reasons for changes in these lakes on the Tibetan Plateau were analyzed, including precipitation and evaporation from meteorological data, glacier meltwater from the Chinese glacier inventories. Several key problems, e.g. challenges of monitoring water balance, limitations to glacial area detection, uncertainties in detecting lake water-level variations and variable region boundaries of lake change types on the Tibetan Plateau were discussed. This research has most indicative significance to regional climate change.
\end{abstract}

Keywords: inland lake; area variation; glacial retreat; climate change; Tibetan Plateau

Received: 2015-01-15 Accepted: 2015-10-10

Foundation: The Major State Basic Research Development of China, No.2015CB954101; National Mountain Flood Disaster Investigation Project, No.SHZH-IWHR-57; The National Science and Technology Basic Special Project, No.2011FY11040-2; National Natural Science Foundation of China, No.41171332; The Surveying and Mapping Geoinformation Nonprofit Specific Project, No.201512033

Author: Fang Yue (1986-), PhD, E-mail: fangy@lreis.ac.cn

"Corresponding author: Cheng Weiming (1973-), Professor, E-mail: chengwm@1reis.ac.cn; Zhang Yichi (1978-), E-mail: zhangych@1reis.ac.cn 


\section{Introduction}

Alpine lakes in remote alpine regions generally remain in a natural state because there is minimal impact from human activities. Therefore, these lakes are regarded as sensitive indicators of global climate change (Guo et al., 2003; Hu et al., 2007) and variations in the level and area of alpine lakes reflect regional change (Ding et al., 2006). Moreover, alpine lakes are important water resources in many arid and semiarid regions (Fan and Li, 1984; Qin, 1999) and changes in these resources have significant effects on local climate (Hu et al., 2002; Angel and Kunkel, 2010). Over the past 40 years, climate change has been an important factor in the evolution of alpine lakes (Shi and Zhang, 1995) because the water cycle in drainage basins has being changed related to rainfall, evaporation, and meltwater from glaciers and snow (Ma et al., 2003). Therefore, it is important to understand the causes and effects of changes in alpine lakes.

Changes in alpine glaciers are another important indicator of climatic change. The nine mountain ranges of the Tibetan Plateau have a total of 36,734 glaciers and constitute the main alpine glacier area in the world (Liu et al., 2015). Many scientists have analyzed the relationship between climate change and glacier retreat based on topographic and remote sensing data (Aizen et al., 2007; Kutuzov and Shahgedanova, 2009; Wang et al., 2011). There has been a marked decrease in the area of alpine glaciers over the past 40 years (Bolch, 2007; Kong and Pang, 2012). A marked decrease in glacier area has also been observed in the mountains of the Tibetan Plateau in China (Bolch et al., 2010; Yao et al., 2013) and in the peripheral, lower-elevation ranges of Central Asia near densely populated forelands (Sorg et al., 2012).

A clear understanding of the impact of climate change on inland lakes and glacial retreat is crucial for the accurate evaluation of water resources and for the prediction of future changes. Numerous studies have shown that the surface areas of inland lakes in arid and semiarid regions have decreased considerably since 1950 (e.g., Fan and Li, 1984; Hu et al., 2002; Gao and Jia, 2005; Ding et al., 2006; Li et al., 2011; Bai et al., 2011; Kropáček et al., 2012). The levels of most lakes in the basin regions of Qinghai in China (Gao and Jia, 2005), Australia (Jones et al., 2001), Africa (Mercier et al., 2002), and parts of North America such as North Dakota (Donald and Thomas, 1997) have declined because of the combined effects of drought, warming, and human activities. Moreover, many lakes (e.g., Aibi Lake, Ayding Lake, and Lop Nur) in Xinjiang in northwest China are shrinking and some have dried up completely (Fan and Li, 1984; Qin, 1999; Bai et al., 2011). Conversely, water levels in a small number of mountain lakes in Xinjiang (Gao and Jia, 2005; Ding et al., 2006; Hu et al., 2007; Bai et al., 2011) and on the Tibetan Plateau (Liu et al., 2009; Zhang et al., 2011a; Wang et al., 2013; Zhang et al., 2014a; Yan and Zheng., 2015) have risen in response to increased precipitation and melt glacier (Aizen et al., 1996; Kutuzov and Shahgedanova, 2009). The results of these studies indicate that lakes could be affected by climate change.

Traditionally, lake change can be monitored using direct observations from meteorological or hydrological stations (Chu et al., 2012; Meng et al., 2012; Qi and Zheng, 2006; Zhang et al., 2011b), which can address changes in lake water levels and shorelines at local spatial and temporal scales. However, most lakes on the Tibetan Plateau are located in sparsely populated areas and data from systematic observations are lacking. Thus, Many scientists 
obtained changed water level and area of lakes on the Tibetan Plateau by means of remote sensing techniques and field survey (Liu et al., 2008; Wang et al., 2011; Zhang et al., 2011a; Wang et al., 2013; Zhang et al., 2014a; Yan and Zheng, 2015), but there are few researches on the regional temporal differences and spatial heterogeneity of these alpine lakes, and reasons for changes in these lakes were rarely analyzed in detail from water-supplying factors, such as precipitation and glacier meltwater over the past decades.

Thus, the purpose of this article is to analyze the temporal differences and spatial heterogeneity of alpine lakes on the Tibetan Plateau, to address the reasons for changes in these lakes in detail using data from previous research over the past 40 years. Firstly, typical 35 alpine lakes on the Tibetan Plateau were selected to investigate changes in lake water level and area. The temporal differences of these lakes could be divided into several groups according to falling or rising tendency for area variations. The spatial heterogeneity of area changes of these lakes was analyzed by means of geomorphological regions. And the water level changes of these lakes were analyzed by means of former research. Secondly, reasons for changes in these lakes on the Tibetan Plateau were analyzed, including precipitation and evaporation from long-term meteorological records, glacier meltwater from the first and second Chinese glacier inventories. Finally, some key problems, e.g. challenges of monitoring water balance, limitations to glacial area detection, uncertainties in detecting lake water-level variations and variable region boundaries of lake change types on the Tibetan Plateau were discussed. This research has most indicative significance to regional climate change.

\section{Regional setting}

The Tibetan Plateau, referred to as the "Water Tower of Asia" and "The Third Pole", has important roles in global climate dynamics and the Asian monsoon system (Krause et al., 2010). The Tibetan Plateau has both the highest number of lakes $(1055,39.2 \%)$ and the largest total lake area $\left(41,831.7 \mathrm{~km}^{2}, 51.4 \%\right)$ among the regions of China. Of these 1,055 lakes, 389 are more than $10.0 \mathrm{~km}^{2}$ each and occupy a total area of $39,603.7 \mathrm{~km}^{2}$ (Ma et al., 2010). The highland region of the Tibetan Plateau are the highest terrain in China, which includes plains, tablelands, hills and mountains with mean elevations more than $4000 \mathrm{~m}$ and $75 \%$ feature glaciers and periglacial landforms. The present study area can be divided into six geomorphological regions according to tectonic and landform features: the Himalayan Mountain region, the Kunlun Mountain region, the Qilian Mountain region, the Karakoram Mountain region, the Qaidam Basin, and the Changtang Plateau (Li et al., 2013) (Figure 1).

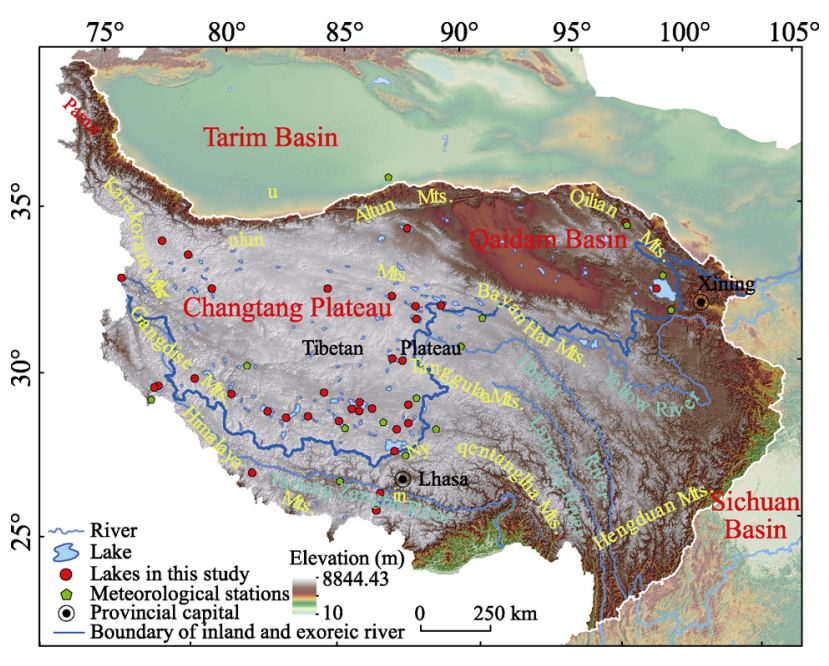

Figure 1 Location and inland lakes of the Tibetan Plateau in China 


\section{Materials}

\subsection{Documented lake changes}

Lake water level and area data for 35 lakes on the Tibetan Plateau recorded over the past 40 years were obtained from previous studies and used to investigate changes in the lakes associated with climate change and human activities. Details of the 35 lakes and the previous studies are summarized in Table 1.

Table 1 Summary of the 35 alpine lakes on the Tibetan Plateau included in the present study

\begin{tabular}{|c|c|c|c|c|}
\hline Lake Name & $\begin{array}{c}\text { Eleva- } \\
\operatorname{tion}(\mathrm{m})\end{array}$ & Supplement & $\begin{array}{l}\text { Geomorphological } \\
\text { regions }\end{array}$ & Sources \\
\hline Qinghai Lake & 3200 & $\begin{array}{l}\text { Runoff, spring, } \\
\text { precipitation }\end{array}$ & Qaidam Basin & $\begin{array}{l}\text { Shao et al. (2007); Liu et al. (2008); } \\
\text { Song et al. (2013); Zhang et al. } \\
\text { (2014a); Yan et al. (2015) }\end{array}$ \\
\hline Har Lake & 4078 & $\begin{array}{l}\text { Glacier melting, } \\
\text { precipitation }\end{array}$ & Qilian Mountains & $\begin{array}{l}\text { Guo et al. (2003); Shao et al. (2007); } \\
\text { Song et al. (2013); Yan et al. (2014) }\end{array}$ \\
\hline Ulan Ul Lake & 4917 & $\begin{array}{l}\text { Runoff, glacier } \\
\text { melting }\end{array}$ & Changtang Plateau & $\begin{array}{l}\text { Shao et al. (2007); Song et al. (2013); } \\
\text { Jiang et al. (2014); Yan et al. (2014) }\end{array}$ \\
\hline Xijin Ulan Lake & 4769 & $\begin{array}{l}\text { Runoff, glacier } \\
\text { melting }\end{array}$ & Changtang Plateau & $\begin{array}{l}\text { Wang et al. (2013); Yao et al. (2013); } \\
\text { Yan et al. (2014) }\end{array}$ \\
\hline $\begin{array}{l}\text { Dogai Coring } \\
\text { Lake }\end{array}$ & 4782 & Glacier melting & Changtang Plateau & $\begin{array}{l}\text { Wang et al. (2013); Yao et al. (2013); } \\
\text { Yan et al. (2014) }\end{array}$ \\
\hline Hoh Xil Lake & 4878 & Glacier melting & Changtang Plateau & $\begin{array}{l}\text { Wang et al. (2013); Yao et al. (2013); } \\
\text { Yan et al. (2014) }\end{array}$ \\
\hline Chibuzhang Co & 4931 & $\begin{array}{l}\text { Glacier melting, } \\
\text { runoff }\end{array}$ & Changtang Plateau & $\begin{array}{l}\text { Shao et al. (2007); Wan et al. (2014); } \\
\text { Yan et al. (2014) }\end{array}$ \\
\hline Ayakekum Lake & 3876 & Glacier melting & Altun Mountains & $\begin{array}{l}\text { Shao et al. (2007); Song et al. (2013); } \\
\text { Li et al. (2014) }\end{array}$ \\
\hline Aksai Chin & 4990 & Runoff & Changtang Plateau & Li et al. (2014) \\
\hline Siling Co & 4530 & $\begin{array}{l}\text { Glacier melting, } \\
\text { precipitation }\end{array}$ & $\begin{array}{l}\text { Gangdise Moun- } \\
\text { tains }\end{array}$ & $\begin{array}{l}\text { Shao et al. (2007); Bian et al. (2010); } \\
\text { Zhang et al. (2011c); Liao et al. } \\
\text { (2013); Song et al. (2013) }\end{array}$ \\
\hline Nam Co & 4718 & $\begin{array}{l}\text { Precipitation, } \\
\text { glacier melting }\end{array}$ & $\begin{array}{l}\text { Gangdise Moun- } \\
\text { tains }\end{array}$ & $\begin{array}{l}\text { Wu et al. (2007); Niu et al. }(2008) ; \\
\text { Chen et al. }(2009) ; \text { Zhu et al. }(2010) ; \\
\text { La et al. }(2011) ; \text { Ma et al. }(2012) ; \\
\text { Liao et al. }(2013) ; \text { Song et al. }(2013) \text {; } \\
\text { Song et al. (2014) }\end{array}$ \\
\hline $\begin{array}{l}\text { Yamzhog } \\
\text { Yumco Lake }\end{array}$ & 4440 & $\begin{array}{l}\text { Precipitation, } \\
\text { glacier melting }\end{array}$ & $\begin{array}{l}\text { Himalaya } \\
\text { Mountains }\end{array}$ & $\begin{array}{l}\text { Liu (1995); Shao et al. (2007); } \\
\text { Bian et al. (2009); Chu et al. (2012); } \\
\text { Liao et al. (2013); Song et al. (2013); } \\
\text { Zhao et al. (2014) }\end{array}$ \\
\hline Zige Tang Co & 4560 & $\begin{array}{l}\text { Runoff, } \\
\text { precipitation }\end{array}$ & $\begin{array}{l}\text { Tanggula } \\
\text { Mountains }\end{array}$ & Lei et al. (2009); Song et al. (2013) \\
\hline Zhari Nam Co & 4613 & $\begin{array}{l}\text { Glacier melting, } \\
\text { precipitation }\end{array}$ & Changtang Plateau & $\begin{array}{l}\text { Shao et al. (2007); Zhang et al. } \\
\text { (2011b); Liao et al. (2013); Song et al. } \\
\text { (2013); Deji et al. (2014); Zhang et al. } \\
\text { (2014b) }\end{array}$ \\
\hline Tangra Yum Co & 4528 & $\begin{array}{l}\text { Precipitation, } \\
\text { runoff }\end{array}$ & Changtang Plateau & $\begin{array}{l}\text { Shao et al. (2007); Huang et al. } \\
\text { (2012); La et al. (2012); Liao et al. } \\
\text { (2013); Song et al. (2013) }\end{array}$ \\
\hline
\end{tabular}


(Continued)

\begin{tabular}{|c|c|c|c|c|}
\hline Lake Name & $\begin{array}{l}\text { Eleva- } \\
\operatorname{tion}(\mathrm{m})\end{array}$ & Supplement & $\begin{array}{l}\text { Geomorphological } \\
\text { regions }\end{array}$ & Sources \\
\hline Cuona Lake & 4800 & $\begin{array}{l}\text { Runoff, } \\
\text { precipitation }\end{array}$ & Changtang Plateau & Huang et al. (2012) \\
\hline Mapam Yum Co & 6638 & $\begin{array}{l}\text { Glacier melting, } \\
\text { precipitation }\end{array}$ & $\begin{array}{l}\text { Himalayan } \\
\text { Mountains }\end{array}$ & $\begin{array}{l}\text { Guo et al. (2007); Niu et al. (2008); } \\
\text { Ye et al. (2008); La et al. }(2011) ; \\
\text { Song et al. }(2013) ; \text { Li et al. }(2014) ; \\
\text { Zhang et al. }(2014 b)\end{array}$ \\
\hline $\begin{array}{l}\text { Lhanag-tso } \\
\text { Lake }\end{array}$ & 4573 & Runoff & $\begin{array}{l}\text { Himalayan } \\
\text { Mountains }\end{array}$ & La et al. (2011); Liao et al. (2013) \\
\hline Co'e Lake & 4562 & $\begin{array}{l}\text { Runoff, } \\
\text { precipitation }\end{array}$ & $\begin{array}{l}\text { Gangdise Moun- } \\
\text { tains }\end{array}$ & Bian et al. (2010); Huang et al. (2012) \\
\hline Yagen Co & 4866 & $\begin{array}{l}\text { Runoff, } \\
\text { precipitation }\end{array}$ & $\begin{array}{l}\text { Tanggula Moun- } \\
\text { tains }\end{array}$ & Bian et al. (2010) \\
\hline Dorsoidong Co & 4749 & $\begin{array}{l}\text { Glacier melting, } \\
\text { runoff }\end{array}$ & $\begin{array}{l}\text { Tanggula Moun- } \\
\text { tains }\end{array}$ & Song et al. (2013) \\
\hline Bange Co & 4527 & $\begin{array}{l}\text { Runoff, } \\
\text { precipitation }\end{array}$ & Changtang Plateau & Huang et al. (2012) \\
\hline Dagze Co & 4461 & $\begin{array}{l}\text { Glacier melting, } \\
\text { precipitation }\end{array}$ & Changtang Plateau & Qiao et al. (2010); Song et al. (2013) \\
\hline Geren Co & 4650 & $\begin{array}{l}\text { Runoff, } \\
\text { precipitation }\end{array}$ & $\begin{array}{l}\text { Gangdise Moun- } \\
\text { tains }\end{array}$ & Huang et al. (2012) \\
\hline Angzi Co & 4683 & $\begin{array}{l}\text { Runoff, } \\
\text { precipitation }\end{array}$ & Changtang Plateau & Huang et al. (2012); Song et al. (2013) \\
\hline Bamu Co & 4555 & $\begin{array}{l}\text { Runoff, } \\
\text { precipitation }\end{array}$ & $\begin{array}{l}\text { Tanggula Moun- } \\
\text { tains }\end{array}$ & Huang et al. (2012) \\
\hline Peng Co & 4522 & $\begin{array}{l}\text { Runoff, } \\
\text { precipitation }\end{array}$ & $\begin{array}{l}\text { Tanggula Moun- } \\
\text { tains }\end{array}$ & Huang et al. (2012) \\
\hline $\begin{array}{l}\text { Margai CaKa } \\
\text { Lake }\end{array}$ & 4785 & $\begin{array}{l}\text { Precipitation, } \\
\text { glacier melting }\end{array}$ & Changtang Plateau & Li and Sheng (2013) \\
\hline Meima Co & 4920 & Glacier melting & Changtang Plateau & Li and Sheng (2013) \\
\hline $\begin{array}{l}\text { Ngangla Ringco } \\
\text { Lake }\end{array}$ & 4715 & $\begin{array}{l}\text { Glacier melting, } \\
\text { precipitation }\end{array}$ & $\begin{array}{l}\text { Gangdise Moun- } \\
\text { tains }\end{array}$ & $\begin{array}{l}\text { Shao et al. (2007); Zhang et al. } \\
\text { (2014b); Song et al. (2013) }\end{array}$ \\
\hline Puma Yum Co & 5030 & $\begin{array}{l}\text { Runoff, glacier } \\
\text { melting }\end{array}$ & $\begin{array}{l}\text { Himalayan } \\
\text { Mountains }\end{array}$ & $\begin{array}{l}\text { Niu et al. (2008); Liao et al. (2013); } \\
\text { Song et al. (2013); Zhang et al. } \\
(2014 b)\end{array}$ \\
\hline Bangong Co & 4242 & $\begin{array}{l}\text { Runoff, glacier } \\
\text { melting }\end{array}$ & Kunlun Mountains & Shao et al. (2007); Song et al. (2013) \\
\hline Peiku Co & 4590 & $\begin{array}{l}\text { Runoff, } \\
\text { precipitation }\end{array}$ & $\begin{array}{l}\text { Himalayan } \\
\text { Mountains }\end{array}$ & $\begin{array}{l}\text { Liao et al. (2013); Zhang et al. } \\
\text { (2014b) }\end{array}$ \\
\hline Gozha Co & 5080 & Glacier melting & Changtang Plateau & Liao et al. (2013) \\
\hline Tarong Co & 4566 & $\begin{array}{l}\text { Precipitation, } \\
\text { glacier melting }\end{array}$ & $\begin{array}{l}\text { Himalayan } \\
\text { Mountains }\end{array}$ & Zhang et al. (2014b) \\
\hline
\end{tabular}

\subsection{Meteorological data}


Sharing Service System (http://cdc.nmic.cn/home.do). In the present study, datasets of monthly $0.5^{\circ} \times 0.5^{\circ}$ grid-based precipitation/temperature over China from 1970 to 2010 were selected to analyze climate changes in different regions on the Tibetan Plateau (Table 2).

Table 2 Locations of alpine lakes on the Tibetan Plateau

\begin{tabular}{ll}
\hline \multicolumn{1}{c}{ Regions } & \multicolumn{1}{c}{ Lakes } \\
\hline Himalayan Mountain region & $\begin{array}{l}\text { Ngangla Ringco Lake, Lhanag-tso Lake, Mapam Yum Co } \\
\text { Yamzhog Yumco Lake, Puma Yum Co, Cuona Lake, Peiku Co, Tarong Co }\end{array}$ \\
\hline Karakoram Mountain region & Bangong Co \\
\hline Changtang Plateau & $\begin{array}{l}\text { Nam Co, Siling Co, Tangra Yum Co, Zhari Nam Co, Angzi Co, Geren Co, Yagen } \\
\text { Co, Co'e Lake, Dagze Co, Bamu Co, Peng Co, Zige Tang Co, Bange Co, Dorsoi- } \\
\text { dong Co, Chibuzhang Co, Ulan Ul Lake, Xijin Ulan Lake, Dogai Coring Lake, } \\
\text { Margai CaKa Lake, Meima Co, Gozha Co, Aksai Chin Lake }\end{array}$ \\
\hline Kunlun Mountain region & Ayakekum Lake \\
\hline Qaidam Basin & Qinghai Lake \\
\hline Qilian Mountain region & Har Lake \\
\hline
\end{tabular}

\subsection{Chinese glacier inventories}

The first and second Chinese glacier inventories were compiled based on remote sensing images. Prior to the 2000s there were 46,298 glaciers with an area of $59,406 \mathrm{~km}^{2}$ in China (Liu et al., 2000). Currently there are 48,571 glaciers with a total area of $51,800 \mathrm{~km}^{2}$. About $80 \%$ of the total area of glaciers in China is distributed in an altitudinal band between 4,500 and 6,500 $\mathrm{m}$ above sea level, with regional differences depending on the general elevations of various mountains. The glaciers are spatially distributed among 14 mountain ranges and plateaus in Western China, including the Kunlun, Karakoram, and Himalayan Mountains (Liu et al., 2015).

\section{Analysis of variations in lake area and water level}

Because the absence of sufficient traditional observational data of alpine lakes on the Tibetan Plateau, the data analysis from previous research on water area and water level of 35 alpine lakes showed the consistency in the last 40 years. The lake changes presented an obvious spatial and temporal heterogeneity throughout the entire Tibetan Plateau.

\subsection{Changes in lake water area of the Tibetan Plateau}

\subsubsection{Temporal heterogeneity of lake area}

Based on temporal heterogeneity, changes in area of the large lakes on the Tibetan Plateau could be grouped into five types and six subtypes: rising (subtypes: linear rising, concave exponential rising, and convex logarithmic rising), falling-rising (subtypes: gentle falling-steep rising, steep falling-steep rising, and steep falling-gentle rising), rising-falling, fluctuating, and falling.

Lakes classified as rising (type I) showed marked increases in water area with substantial increasing in area by $>30 \%$ in the past 40 years. Type I lakes classified as linear rising (subtype i) showed similar steady linear increases in area over the past 40 years. The type I 
(subtype i) lakes were Bamu Co, Peng Co, Zige Tang Co and Nam Co with increases in area of $35.32 \%, 30.96 \%, 20.22 \%$, and $4.01 \%$, respectively (Figure 2).

(a) Bamu $\mathrm{Co}$

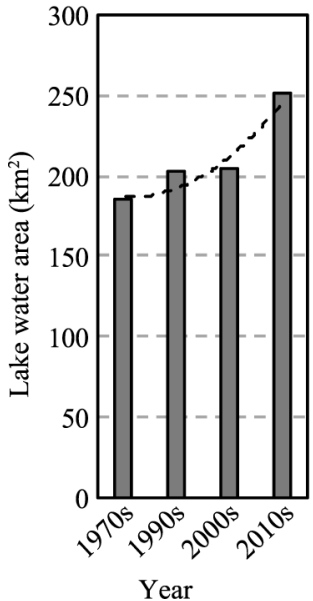

(b) Peng Co

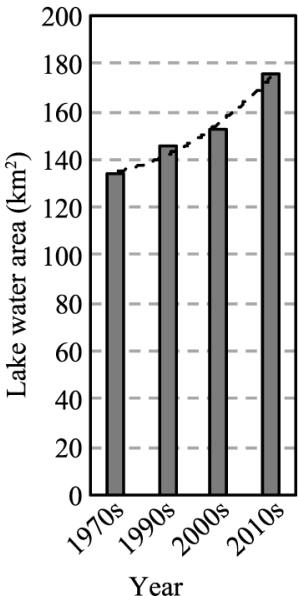

(c) Zige Tang Co

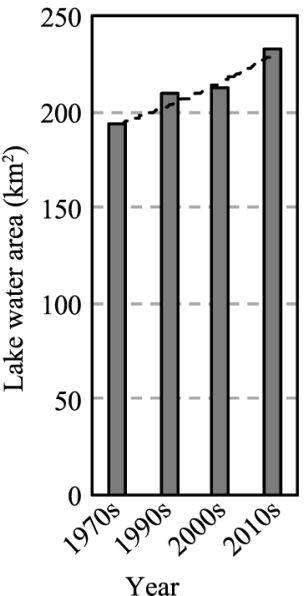

(d) $\mathrm{Nam} \mathrm{Co}$

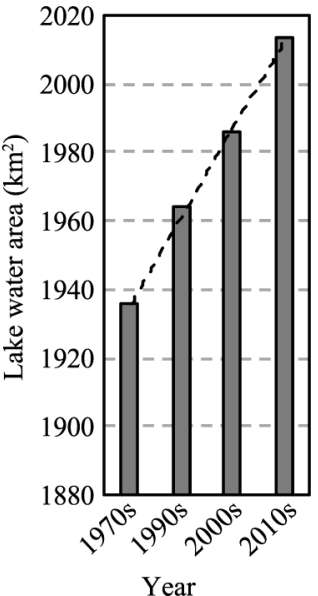

Figure 2 Variation in water area during the past 40 years for linear rising lakes (type I, subtype i)

Type I lakes classified as concave exponential rising (subtype ii) showed steady increases from the 1970s to the 2000s, but more pronounced increases in the 2010s. The type I (subtype ii) lakes were Yagen Co, Ayakekum Lake, Siling Co, Aksai Chin Lake, and Dorsoidong Co. Yagen Co, to the south of Siling Co, showed the largest increase in area of $194.99 \%$ (Bian et al., 2010). Siling Co, with an increase of $39.86 \%$, has expanded by more than 600 $\mathrm{km}^{2}$ since the 1970s and has become the largest alpine lake in Tibet (Figure 3).

(a) Yagen Co

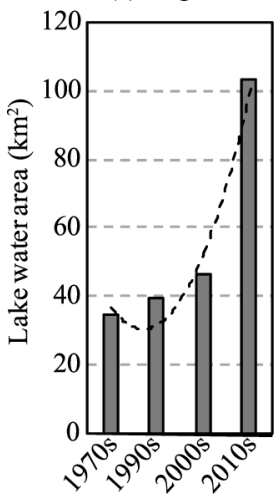

Year (b) Ayakekum Lake

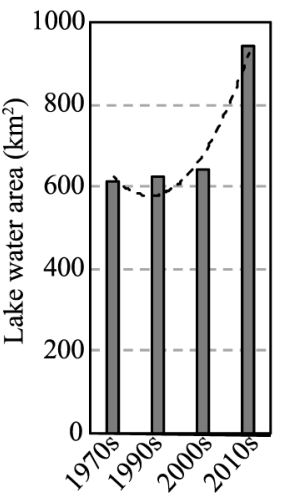

Year (c) Siling Co

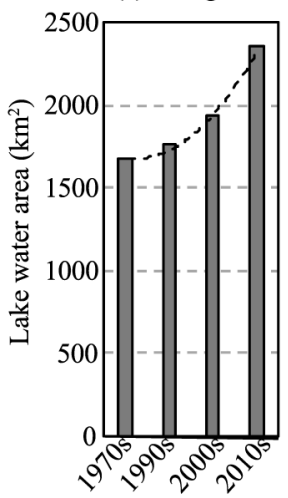

Year (d) Aksai Chin Lake

(e) Dorsoidong Co
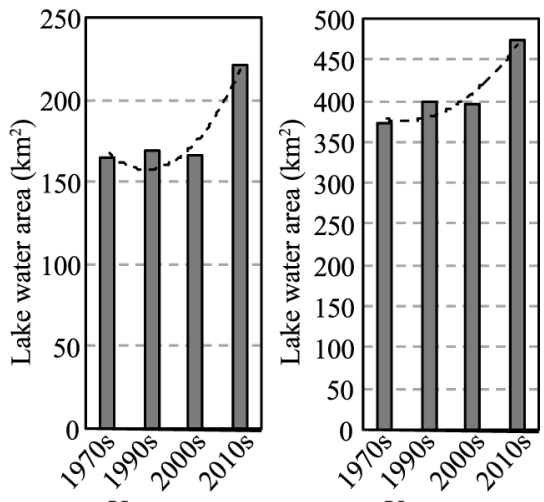

Year

Year

Figure 3 Variation in water area during the past 40 years for concave exponential rising lakes (type I, subtype ii)

Type I lakes classified as convex logarithmic rising (subtype iii) showed rapid increases in area from the 1970s to the 1990s but less dramatic increases since the 1990s. The type I (subtype iii) lakes were Bange Co and Co'e Lake (Figure 4). Bange Co showed a marked increase in area of $177.30 \%$ during the past 40 years.

Lakes classified as falling-rising (type II) showed decreases in area earlier during the study period followed by increases in area in recent years. Type II lakes classified as gentle 
falling-steep rising (subtype i) showed gradual decreases in area from the 1970s to the 2000s followed by marked increases in area since the 2000s. These lakes were Dagze Co, Ulan Ul Lake, Xijin Ulan Lake, Tangra Yum Co, Hoh Xil Lake and Dogai Coring Lake (Figure 5). Overall increases in area of Xijin Ulan Lake, Dagze Co, Ulan Ul Lake, and Dogai Coring Lake were $16.53 \%, 15.59 \%, 14.84 \%$, and $14.22 \%$, respectively (Yao et al., 2013).

Type II lakes classified as steep falling-steep rising (subtype ii) showed marked and rapid decreases in area from the 1970s to 1990s followed by marked and rapid increases. The type II (subtype ii)

(a) Bange Co

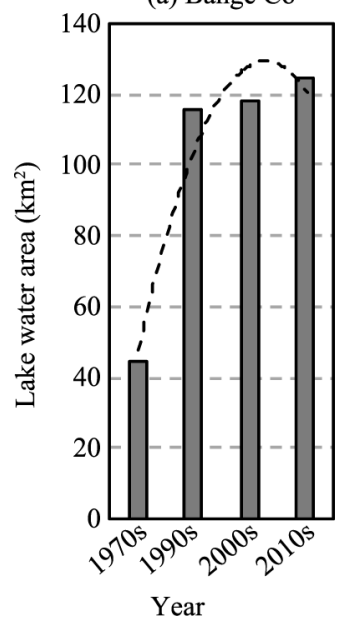

(b) Co'e Lake

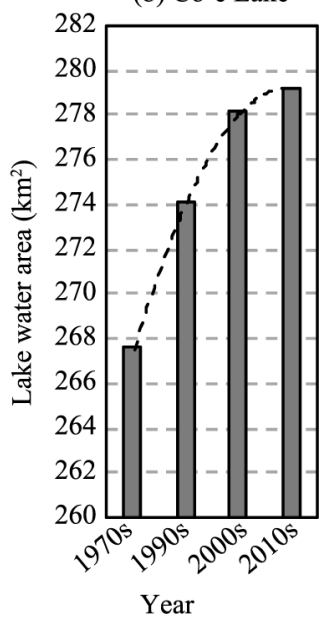

Figure 4 Variation in water area during the past 40 years for convex logarithmic rising lakes (type I, subtype iii) lakes were Margai CaKa Lake, Meima Co, Chibuzhang Co, Angzi Co and Puma Yum Co with overall increases in area of $186.40 \%$, $13.78 \%, 13.24 \%, 7.16 \%$, and 2.38\%, respectively. Chibuzhang Co, Zhari Nam Co, Har Lake, and Tarong Co showed small overall increases in area during the study period (Figure 6).

(a) Dagze Co

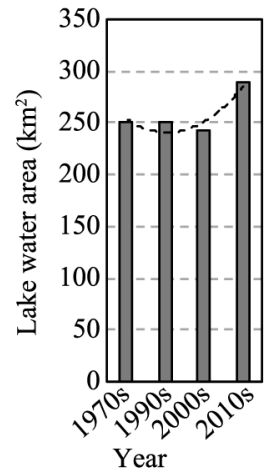

(d) Tangra Yum Co

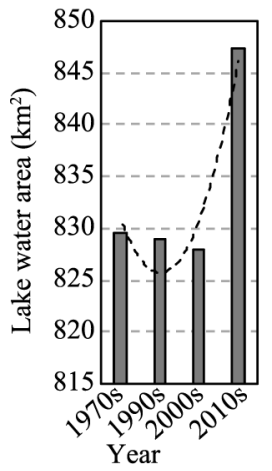

(b) Ulan Ul Lake

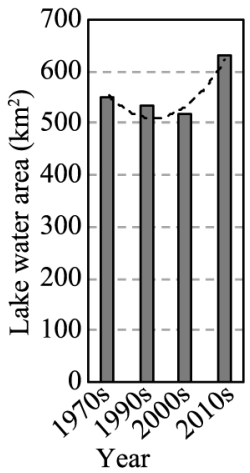

(e) Hoh Xil Lake

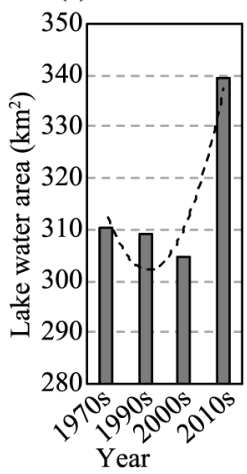

(c) Xjin Ulan Lake

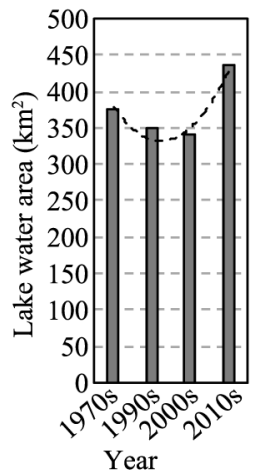

(f) Dogai Coring Lake

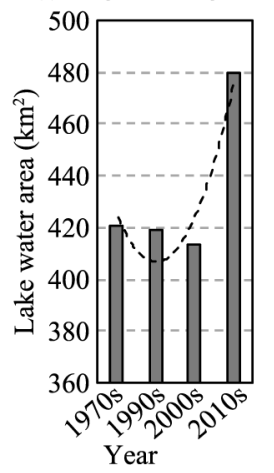

Figure 5 Variation in water area during the past 40 years for gentle falling-steep rising lakes (type II, subtype i) 
(a) Margai CaKa Lake

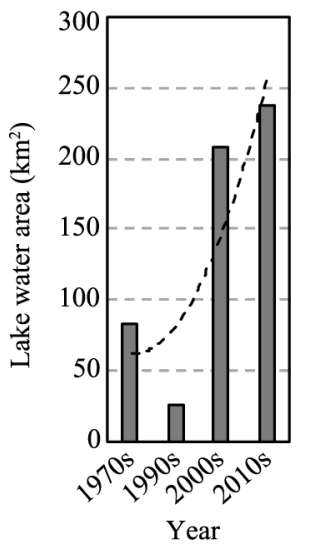

(e) Chibuzhang Co

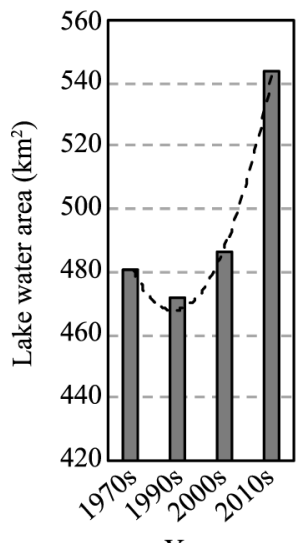

Year (b) Meima Co

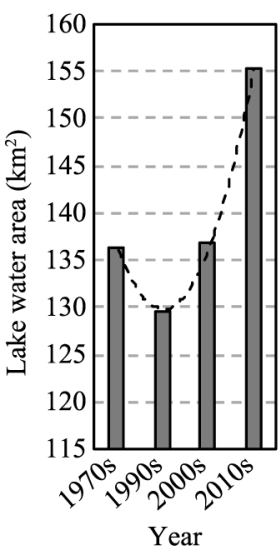

(f) Zhari Nam Lake

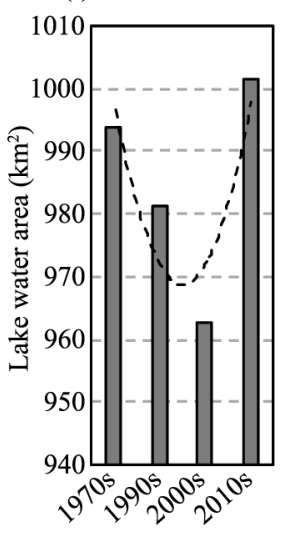

(c) Angzi Co

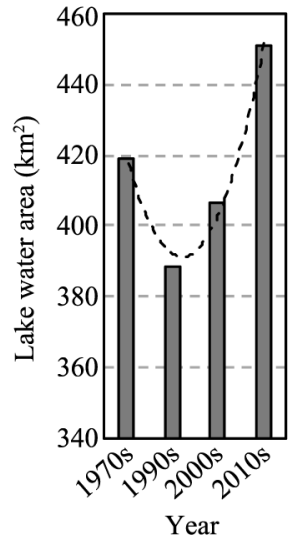

(g) Har Lake

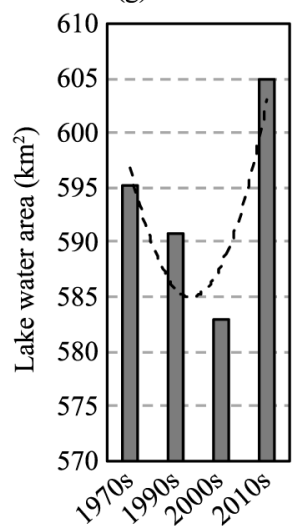

Year (d) Puma Yum Co

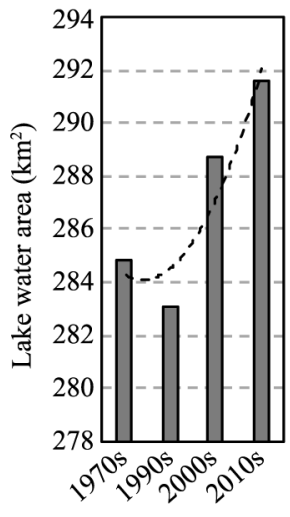

Year

(h) Tarong Co

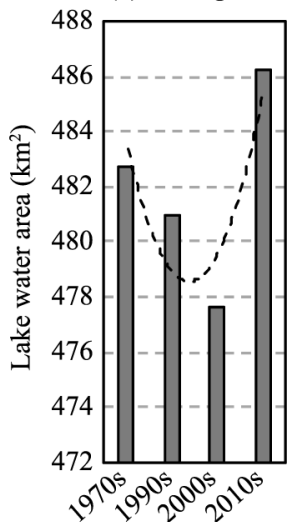

Year

Figure 6 Variation in water area during the past 40 years for steep falling-steep rising lakes (type II, subtype ii)

Type II lakes classified as steep falling-gentle rising (subtype iii) showed marked and rapid decreases in area from the 1970 s to 2000 s followed by slight increases since the 2000s, with overall decreases in area. The type II (subtype iii) lakes were Mapam Yum Co, Bangong Co, Qinghai Lake and Ngangla Ringco Lake. For example, Qinghai Lake underwent a decrease in area of $3.12 \%$ during the past 40 years (Figure 7).

(a) Mapum Yum Co

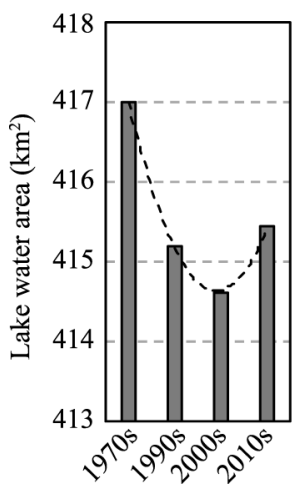

Year (b) Bangong $\mathrm{Co}$

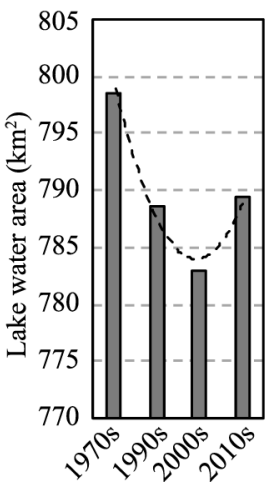

Year (c) Qinghai Lake

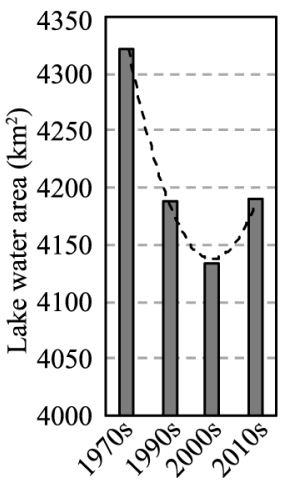

Year (d) Ngangla Ringco Lake

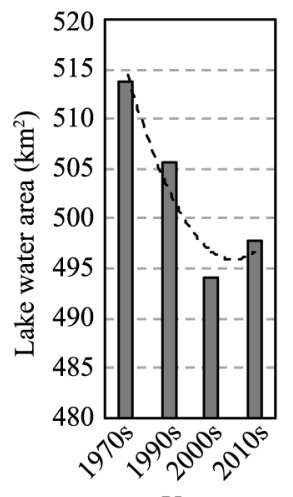

Figure 7 Variation in water area during the past 40 years for steep falling-gentle rising lakes (type II, subtype iii) 
Lakes classified as rising-falling (type III) showed increases in area from the 1970 s to 1990s followed by decreases in area from the 1990s to the 2010s. The type III lakes were Cuona Lake, Geren Co and Peiku Co. The area of Cuona Lake increased $1.11 \%$ during the study period, while Geren Co and Peiku Co decreased by $1.48 \%$ and $3.74 \%$, respectively (Figure 8).

(a) Couna Lake

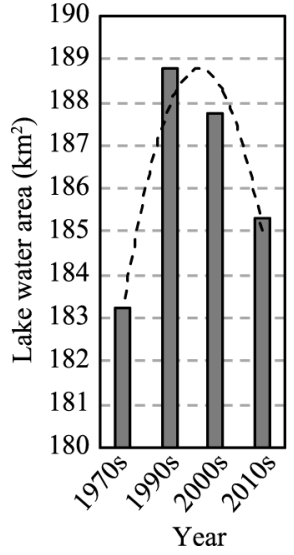

(b) Geren Co

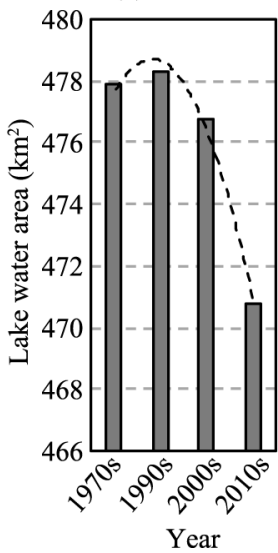

(c) Peiku Co

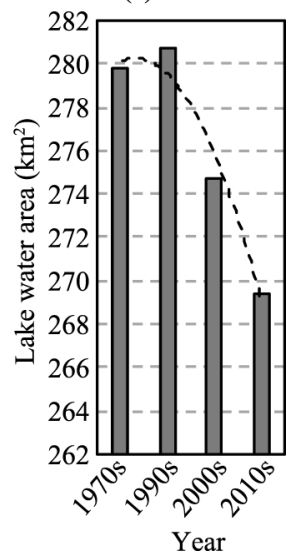

Figure 8 Variation in water area during the past 40 years for rising-falling lakes (type III)

Lakes classified as fluctuating (type IV) showed decreases and increases in area during the study period. The type IV lakes were Yamzhog Yumco Lake and Gozha Co, showing overall decreases in area of $7.97 \%$ and $1.67 \%$, respectively, during the study period (Figures 9a and 9b).

(a) Yamzhog Yumco Lake

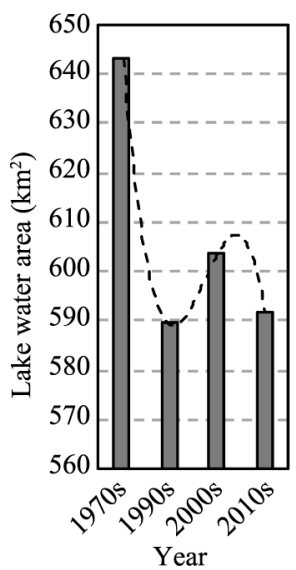

(b) Gozha Co

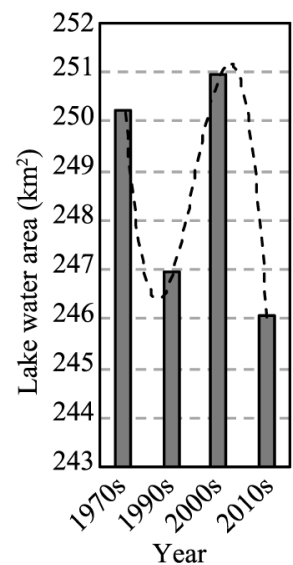

(c) Lhanag-tso Lake

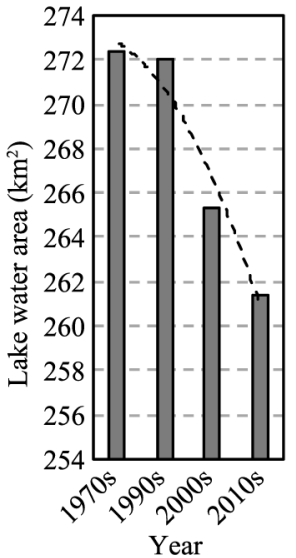

Figure 9 Variation in water area during the past 40 years for fluctuating lakes (type IV) (a) and (b), and falling lakes (type V) (c)

Only one lake was classified as falling (type V). Lhanag-tso Lake showed a steady linear decrease in area during the study period with an overall decrease of $4.94 \%$ (Figure 9c).

\subsubsection{Spatial heterogeneity of lake area}

Investigation of the changes in inland alpine lakes at regional scales or across the whole Tibetan Plateau revealed strong spatial and temporal variability during the past four decades. The changes were consistent with geomorphological boundaries. The Tibetan Plateau can be 
divided into nine subareas based on geomorphologic characteristics. The lakes in the present study were mainly distributed in the Qilian Mountains, the Qaidam Basin, the Kunlun Mountains, the Karakoram Mountains, the Changtang Plateau, and the Himalayan Mountains (Figure 10).

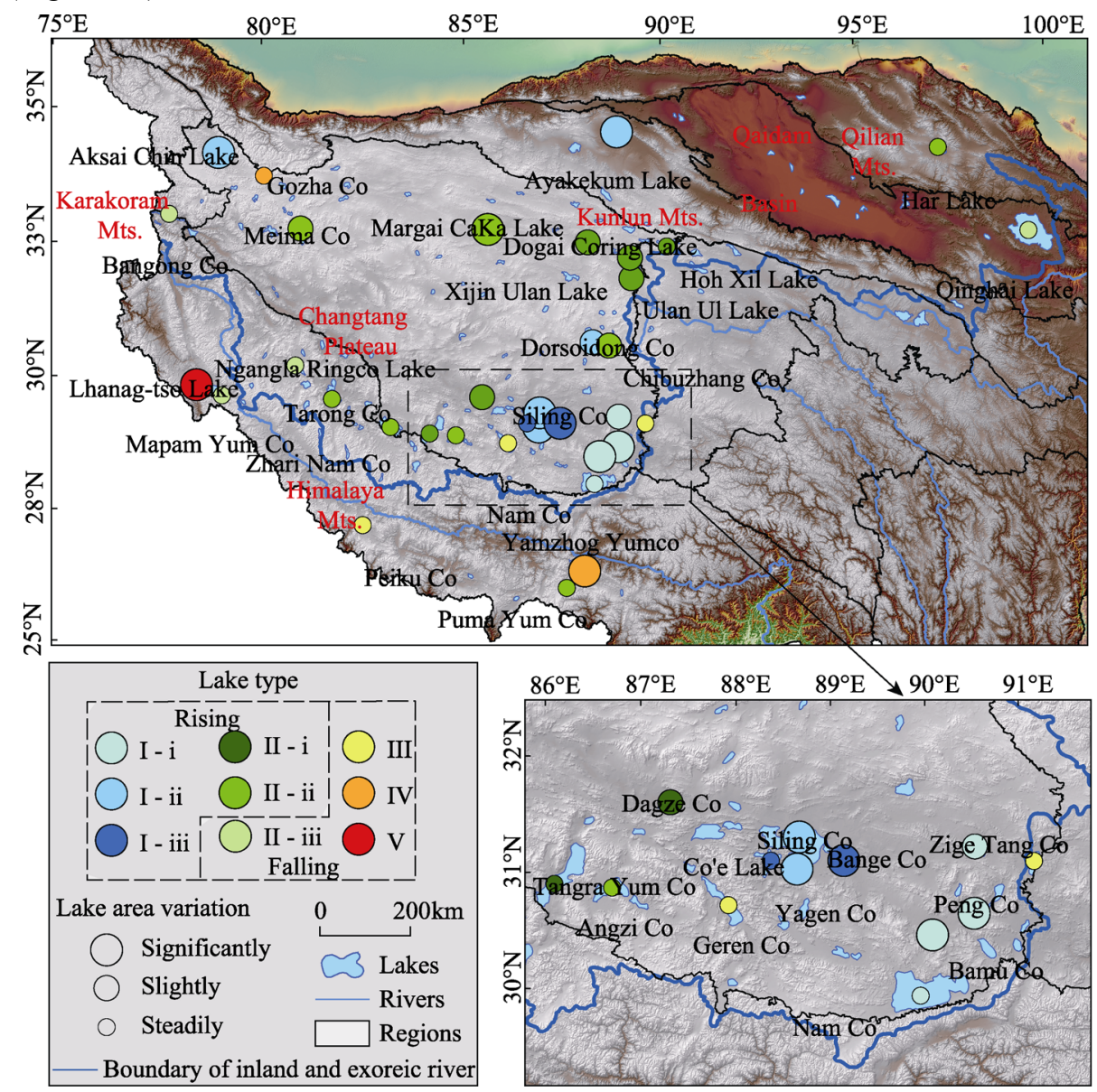

Figure 10 Types of lake area variation on the Tibetan Plateau over the past 40 years

I (i): Linear rising; I (ii): Concave exponential rising; I (iii): Convex logarithmic rising; II (i): Gentle falling-steep rising; II (ii): Steep falling-steep rising; II (iii): Steep falling-gentle rising; III: Rising-falling; IV: Fluctuating; V: Falling

In the Qilian and Kunlun Mountains and the Qaidam Basin, the alpine lakes were sparsely distributed. Qinghai Lake, located in the Qaidam Basin, showed an overall decrease in area of 3\% between the 1970s and 2000 (Zhang et al., 2014b) but the lake showed an obvious increase in area since the 2000s (Zhang et al., 2014b). Har Lake, located in the Qilian Mountains, showed a falling-rising pattern (type II, subtype ii) during the last four decades with a marked increase in area since the 2000s for a total increase in area of $9.6 \mathrm{~km}^{2}$ (Song et al., 2013). Ayakekum Lake in the Kunlun Mountains increased from $614.62 \mathrm{~km}^{2}$ in the $1970 \mathrm{~s}$ to $940.41 \mathrm{~km}^{2}$ in 2010 . Specially, the area increased markedly since the $2000 \mathrm{~s}$, accounting for $91 \%$ of the increase in area over the past 40 years.

On the Changtang Plateau the lakes were mainly concentrated in the Hoh Xil region to the north and the Naqu region to the south. Ulan Ul Lake, Xijin Ulan Lake, Hoh Xil Lake, and 
Dogai Coring Lake were located in the east of the Hoh Xil region and water area increased in these lakes by $14.84 \%, 16.53 \%, 9.36 \%$, and $14.22 \%$, respectively, during the study period (Song et al., 2013). These lakes followed a falling-rising pattern from the 1970s to 2010s, with rapid increases in area since the 2000s (Yao et al., 2013). Margai CaKa Lake and Meima Co, located in the west of the Hoh Xil region, followed a similar falling-rising pattern, but with more marked decreases from the 1970s to the 1990s. The area of Margai CaKa Lake increased greatly during the 1990 s and increased $186.4 \%$ overall during the past 40 years ( $\mathrm{Li}$ and Sheng, 2013). Most of the lakes in the northeast of the Naqu region, including Yagen Co, Bange Co, Siling Co, Bamu Co, Peng Co, Zige Tang Co, Co'e Lake, and Nam Co, showed a marked and steady increase in area between the 1970s and 2010s. Yagen Co showed the largest increase in area (195\%) of the 35 lakes in the present study. The majority of the lakes in the southwest of the Naqu region, including Dagze Co, Zhari Nam Co, and Tangra Yum Co, decreased in area between the 1970s and 2000s and increased in area from the 2000s. However, overall the area of these lakes changed little over the 40-year study period.

In the Himalayan and Karakoram Mountains most of the lakes including Yamzhog Yumco Lake, Peiku Co, Mapam Yum Co, Lhanag-tso Lake, Bangong Co, and Ngangla Ringco Lake showed fluctuations in area, but the lake areas were smaller in 2010 compared with the 1970s. Yamzhog Yumco Lake experienced the most severe shrinkage of $51.29 \mathrm{~km}^{2}$ in the past four decades. The area of Lhanag-tso Lake has also been falling continuously over the past four decades. Puma Yum Co and Tarong Co showed a small overall increase in area after decreasing during the 1970 s to 2000 s.

\subsection{Changes in lake water level of the Tibetan Plateau}

Lake water level is an important parameter for water storage estimation, and a sensitive indicator of lake water balance and regional climatic variability at timescales of years to decades (Ponchaut and Cazenave, 1998). Traditionally, water-level changes in lakes have been monitored using gauge data (Mercier et al., 2002). For some specific lakes, trends in water-level changes can be calculated from continuous observation data. However, for many lakes, particularly those in remote areas and in developing countries, routine in situ measurements of water change are not available (Chipman and Lillesand, 2007). As an alternative, altimetry data for specific lake areas obtained from different satellite campaigns can be used to detect changes in water levels (Urban et al., 2008). Methods to derive time series of lake water levels from the Ice, Cloud, and land Elevation Satellite Geoscience Laser Altimeter System (ICESat/GLAS) data have been summarized by Phan et al. (2012) and Wang et al. (2013).

Water-level changes for 26 typical inland lakes on the Tibetan Plateau were examined based on ICESat altimetry data (Zhang et al., 2011b; Song et al., 2013; Wang et al., 2013). Among the 26 lakes, 22 showed an upward tendency and four showed a downward tendency for water level during 2003 to 2009 (Table 3). Siling Co, Meima Co, Aksai Chin Lake, Angzi Co, and Dorsoidong Co had marked rises in water level. The average rise in lake level during 2003 to 2009 was $0.17 \mathrm{~m} /$ year. Water levels increased by $0-0.2 \mathrm{~m} /$ year in $34.62 \%$ of the lakes, by $0.2-0.4 \mathrm{~m} /$ year in $42.31 \%$, and $>0.4 \mathrm{~m} /$ year in $7.69 \%$, while in $15.38 \%$ of the lakes levels decreased by $0.42-0 \mathrm{~m} /$ year. The water-level changes in different lakes over the 
Tibetan Plateau also showed considerable spatial heterogeneity. In accordance with the findings for water area discussed in section 4.1, most lakes in the inner and northern part of the plateau tended to show increases in water levels, while the lakes in the Himalayan Mountains tended to show decreases in water levels.

Table 3 Variations in water levels of alpine lakes on the Tibetan Plateau (m)

\begin{tabular}{|c|c|c|c|c|c|c|c|c|c|}
\hline \multirow{2}{*}{$\begin{aligned} \text { Sources } \\
\text { Name }\end{aligned}$} & \multicolumn{3}{|c|}{ Wang et al., 2013} & \multicolumn{3}{|c|}{ Zhang et al., 2011b } & \multicolumn{3}{|c|}{ Song et al., 2013} \\
\hline & 2003 & 2009 & Change & 2003 & 2009 & Change & 2003 & 2009 & Change \\
\hline Yagen Co & 4871.01 & 4871.66 & 0.65 & & & & & & \\
\hline Ayakekum Lake & 3833.458 & 3834.797 & 1.339 & 3878.89 & 3880.49 & 1.6 & 3878.89 & 3880.49 & 1.6 \\
\hline Siling Co & 4539.37 & 4543.76 & 4.39 & 4539.41 & 4543.74 & 4.33 & 4539.37 & 4543.76 & 4.39 \\
\hline Zige Tang Co & 4567.83 & 4569.74 & 1.91 & 4567.87 & 4569.64 & 1.77 & 4533.811 & 4535.675 & 1.864 \\
\hline Nam Co & 4690.71 & 4691.816 & 1.106 & 4723.38 & 4725.43 & 2.05 & 4722.74 & 4725.5 & 2.76 \\
\hline Aksai Chin Lake & 4824.511 & 4826.738 & 2.227 & & & & & & \\
\hline Dorsoidong Co & 4932.96 & 4934.99 & 2.03 & 4932.96 & 4934.99 & 2.03 & & & \\
\hline Meima Co & 4894.563 & 4897.509 & 2.946 & & & & & & \\
\hline Chibuzhang Co & 4897.243 & 4898.635 & 1.392 & & & & & & \\
\hline Angzi Co & 4656.866 & 4658.989 & 2.123 & 4686.8 & 4688.78 & 1.98 & 4686.37 & 4689.24 & 2.87 \\
\hline Puma Yum Co & 4983.02 & 4982.482 & -0.538 & 5011.28 & 5010.77 & -0.51 & 5010.3 & 5011.25 & 0.95 \\
\hline Har Lake & 4031.418 & 4032.069 & 0.651 & 4076.97 & 4077.68 & 0.71 & 4076.75 & 4077.68 & 0.93 \\
\hline Xijin Ulan Lake & 4732.163 & 4733.921 & 1.758 & 4771.89 & 4773.69 & 1.8 & 4771.71 & 4773.69 & 1.98 \\
\hline Ulan U1 Lake & 4817.656 & 4819.054 & 1.398 & & & & 4855.92 & 4858.21 & 2.29 \\
\hline Dogai Coring Lake & 4781.508 & 4782.68 & 1.172 & 4819.1 & 4819.95 & 0.85 & 4818.64 & 4820.18 & 1.54 \\
\hline Hoh Xil Lake & 4846.519 & 4847.82 & 1.301 & 4887.13 & 4888.36 & 1.23 & 4886.93 & 4889 & 2.07 \\
\hline Tangra Yum Co & 4506.757 & 4508.091 & 1.334 & 4536.68 & 4537.46 & 0.78 & 4566.78 & 4568.82 & 2.04 \\
\hline Zhari Nam Co & 4582.81 & 4583.666 & 0.856 & 4612.38 & 4614.57 & 2.19 & 4612.72 & 4614.51 & 1.79 \\
\hline Tarong Co & 4538.862 & 4540.081 & 1.219 & 4567.37 & 4568.58 & 1.21 & 4566.78 & 4568.82 & 2.04 \\
\hline Mapam Yum Co & 4563.032 & 4562.781 & -0.251 & 4586.35 & 4586.76 & 0.41 & 4585.95 & 4587.1 & 1.15 \\
\hline Bangong Co & 4219.819 & 4220.274 & 0.455 & & & & & & \\
\hline Qinghai Lake & 3149.412 & 3149.951 & 0.539 & 3193.35 & 3194.02 & 0.67 & 3193.06 & 3194.1 & 1.04 \\
\hline Ngangla Ringco Lake & 4688.559 & 4688.9 & 0.341 & 4716.39 & 4716.69 & 0.3 & 4715.48 & 4716.79 & 1.31 \\
\hline Geren Co & 4664.91 & 4665.18 & 0.27 & & & & & & \\
\hline Peiku Co & 4553.01 & 4552.049 & -0.961 & 4578.61 & 4578.61 & & & & \\
\hline Yamzhog Yumco Lake & 4411.003 & 4408.481 & -2.522 & 4441.53 & 4438.85 & -2.68 & 4438.94 & 4442.37 & 3.43 \\
\hline
\end{tabular}

\section{Reasons for changes in lakes on the Tibetan Plateau}

The level and area of endorheic lakes are sensitive to complex changes in precipitation, evaporation, and input for glacier meltwater. Recent studies have indicated that the Tibetan Plateau has been experiencing rapid warming since the 1960s (Wang et al., 2008).

\subsection{Climatic changes}

\subsubsection{Precipitation}

The annual mean precipitation decreases from the southeast to the northwest across the Ti- 
betan Plateau and adjacent areas. During the past 40 years, precipitation increased in the east and north of the Tibetan Plateau, whereas it decreased slightly or remained relatively stable in the south and west (Liao et al., 2013). In the present study, changes in precipitation were investigated using data on the mean values around lakes in each region of the Tibetan Plateau. The results were in accordance with the findings of previous studies (Figure 11).
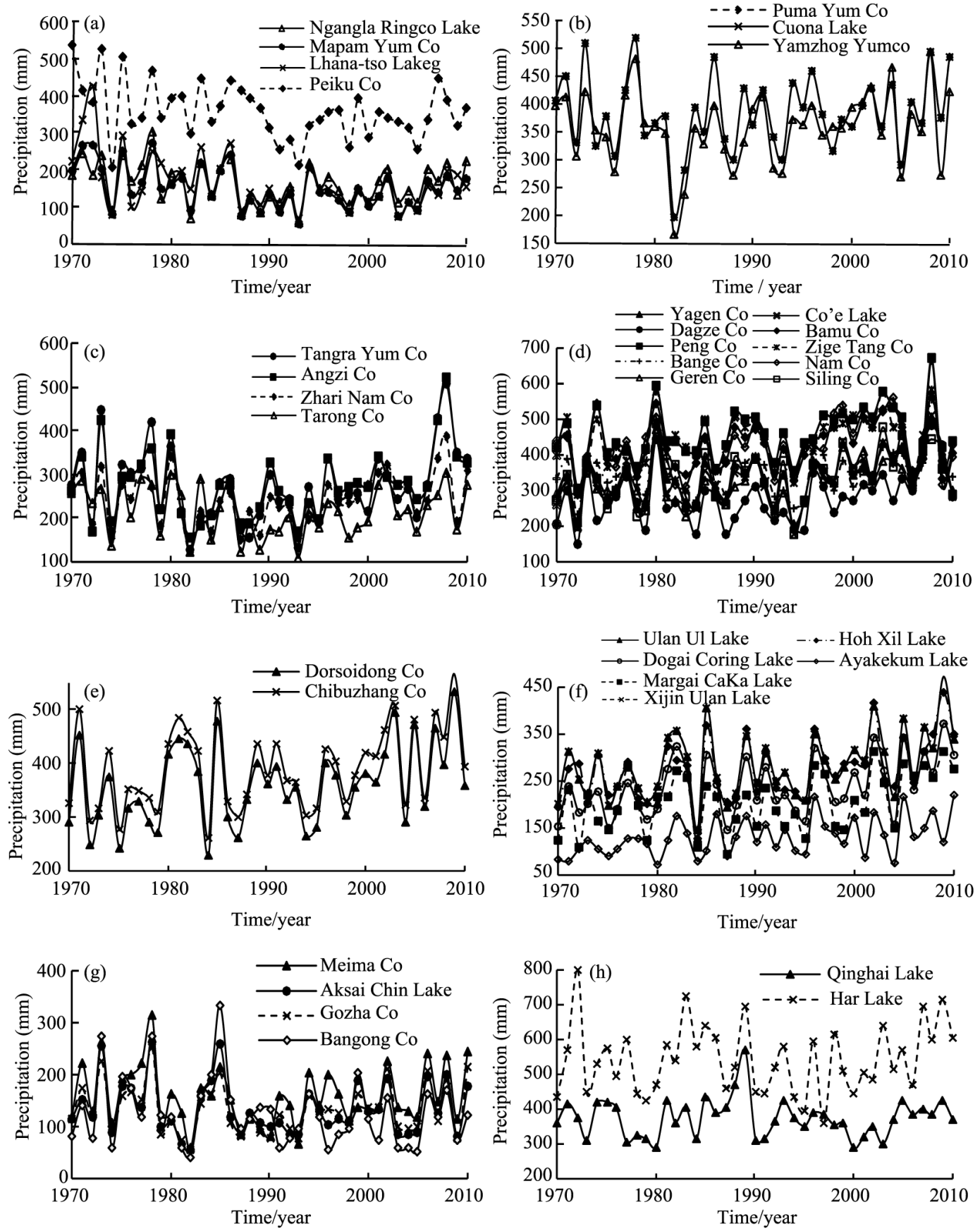

Figure 11 Variations in annual precipitation of different regions on the Tibetan Plateau over the past 40 years

(a) west of the Himalayan Mountains; (b) east of the Himalayan Mountains; (c) west of the Naqu region; (d) east of the Naqu region; (e) north of the Naqu Region; (f) east of the Hoh Xil region and Kunlun Mountains; (g) west of the Hoh Xil region and Karakoram Mountains; (h) the Qaidam Basin and Qilian Mountains 
In the past 40 years, annual mean precipitation at most lakes increased. The largest increase of $28.3 \mathrm{~mm} / 10$ years (10a) occurred at Co'e Lake. However, the annual mean precipitation decreased at the lakes in the west of the Himalayan Mountains on the south of the Tibetan Plateau and the largest change of $-28.4 \mathrm{~mm} / 10 \mathrm{a}$ occurred at Lhanag-tso Lake. Precipitation also decreased in the western Himalayan Mountains and the Karakoram Mountains. The changes in precipitation at Ngangla Ringco Lake, Lhanag-tso Lake, Mapam Yum Co, Bangong Co, and Peiku Co were $-10.1 \mathrm{~mm} / 10 \mathrm{a},-28.4 \mathrm{~mm} / 10 \mathrm{a},-19 \mathrm{~mm} / 10 \mathrm{a},-12.4$ $\mathrm{mm} / 10 \mathrm{a}$, and $-23.1 \mathrm{~mm} / 10 \mathrm{a}$, respectively. In the east of the Himalayan Mountains where Yamzhog Yumco Lake, Puma Yum Co, and Cuona Lake are located, precipitation increased steadily. Precipitation also increased at most lakes in the Naqu region. The fastest rate of increase in annual precipitation occurred in the central part of the Tibetan Plateau with precipitation at Siling Co and Dorsoidong Co increasing at a rate of more than $>20 \mathrm{~mm} / 10 \mathrm{a}$. Precipitation at the lakes in the southeast of the Naqu region, such as Nam Co, increased by about $15 \mathrm{~mm} / 10 \mathrm{a}$ while at the lakes in the southwest of the Naqu region, such as Tangra Yum Co, precipitation increased by $<10 \mathrm{~mm} / 10 \mathrm{a}$. In the Hoh Xil region located in the north of the Tibetan Plateau, the annual precipitation decreased from east to west. At the lakes in the northwest of the Hoh Xil region, such as Meima Co, Gozha Co, and Aksai Chin Lake, the mean annual precipitation was consistently low at about $150 \mathrm{~mm} /$ year. The annual precipitation at Ulan U1 Lake was $283.2 \mathrm{~mm}$ with a slight increase of $24.5 \mathrm{~mm} / 10 \mathrm{a}$. The annual precipitation in the northeast of the Tibetan Plateau was also consistently low. In the past 40 years, Qinghai Lake experienced a sharp increase in precipitation in the late 1980s, then returned to previous levels and remained stable for the past 20 years. The annual precipitation at Har Lake increased slightly by $5.9 \mathrm{~mm} / 10 \mathrm{a}$. Precipitation at Ayakekum Lake in the Kunlun Mountains increased markedly.

\subsubsection{Temperature}

Temperatures throughout the Tibetan Plateau rose from 1961 to 2010 (Du, 2001; Niu et al., 2004; Shi et al., 2007; You et al., 2010; Figure 12). However, the temperature changes in different regions of the Tibetan Plateau showed considerable spatial heterogeneity.

In the past 40 years, temperature in the regions of the lakes studied in this paper rose at a rate of $0.4 \pm 0.1^{\circ} \mathrm{C} / 10 \mathrm{a}$. The temperature around Zhari Nam Co rose most rapidly, increasing by $0.496^{\circ} \mathrm{C} / 10 \mathrm{a}$. Temperatures in the Himalayan Mountains have been fluctuating with an average increment of $7.05^{\circ} \mathrm{C} / 10 \mathrm{a}$ and temperatures in Naqu have been rising at a steady rate with an increase in average annual temperature from $-2.38^{\circ} \mathrm{C}$ in 1970 to $-0.30^{\circ} \mathrm{C}$ in 2010 . The temperature in this region decreased abruptly after 1997 but increased again the following year and has continued to increase rapidly. Hoh Xil has low temperatures year round and the average annual temperature in this region was about $-4.47^{\circ} \mathrm{C}$. The temperatures in the Karakoram Mountains and western Hoh Xil were lower than those in the east of the region and the temperatures fluctuated markedly. In eastern Hoh Xil temperatures increased considerably in the past 10 years. Located in the northeast of the Tibetan Plateau, the Qaidam Basin and Qilian Mountains showed similar increases in temperature. The mean temperature changes at Qinghai Lake and Har Lake were $0.35^{\circ} \mathrm{C} / 10 \mathrm{a}$ and $0.47^{\circ} \mathrm{C} / 10 \mathrm{a}$, respectively.

\subsubsection{Evaporation}

Evaporation is a critical component of the water cycle and its variations affect lake water 

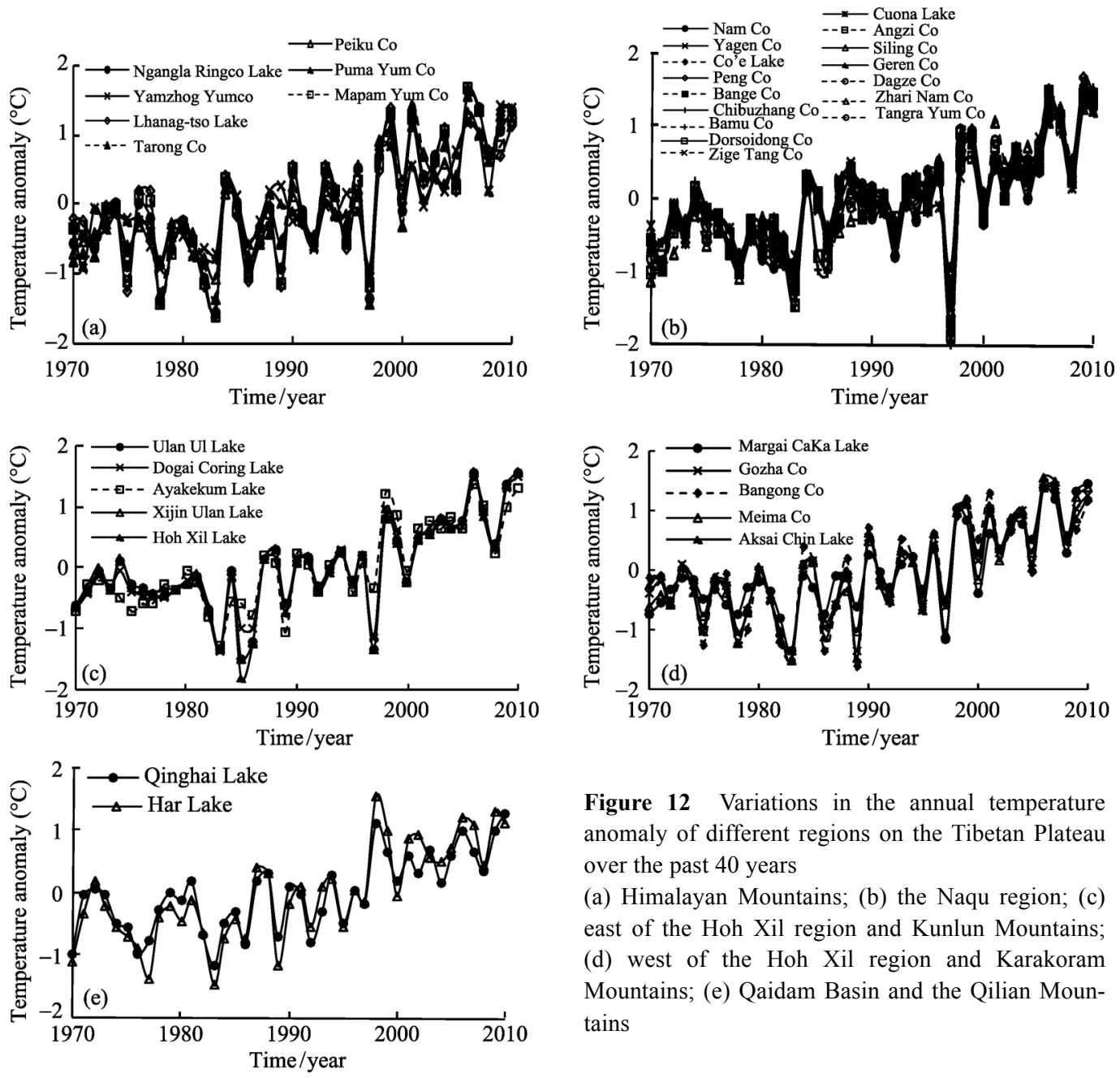

Figure 12 Variations in the annual temperature anomaly of different regions on the Tibetan Plateau over the past 40 years

(a) Himalayan Mountains; (b) the Naqu region; (c) east of the Hoh Xil region and Kunlun Mountains; (d) west of the Hoh Xil region and Karakoram Mountains; (e) Qaidam Basin and the Qilian Mountains

balance. Potential evapotranspiration across the Tibetan Plateau has decreased considerably as a result of decreased wind speed (Zhang et al., 2007, 2009) and solar radiation (Tang et al., 2011). The evaporation on the Tibetan Plateau has been calculated based on the Penman-Monteith model. The results of this study and previous analyses (Liu et al., 2009; Li and Sheng, 2013) indicate that evaporation in most of the northeastern Tibetan Plateau and adjacent areas decreased in the past 40 years, but the changes are inconsistent. Average evaporation in the Qaidam Basin decreased markedly from the 1970s to 2010s. During the period 1961-2000, the mean annual evaporation at Qinghai Lake was 17,862.91 $\mathrm{mm}$ and the annual evaporation change was $-295.13 \mathrm{~mm} / 10 \mathrm{a}$. According to a study by Yao et al. (2013) conducted in Hoh Xil, evaporation at Gerze, Shiquanhe, and Wudaoliang stations was -2.5 $\mathrm{mm} /$ year, $1.8 \mathrm{~mm} /$ year, and $1.1 \mathrm{~mm} /$ year, respectively. Jia et al. (2009) found that evaporation in the Qilian Mountains and Hexi Corridor increased between 1967 and 1974, decreased between 1974 and 1993, and increased again after 1993. The annual evaporation change rate was $-1.67 \mathrm{~mm} /$ year, which indicated that the evaporation in this region showed a decreasing tendency in the past 40 years. 


\subsection{Glacier changes}

In the past 100 years, glaciers on the Tibetan Plateau have been retreating. Based on the two phases of the Chinese glacier inventory, glaciers on the Tibetan Plateau have been declining in number, area, and storage during the past several decades (Table 4). The rate of glacier retreat has increased rapidly since the 1980s under the influence of global warming. The magnitude of glacial retreat is the greatest at the south and east margins of the Tibetan Plateau and at the north of the Tibetan Plateau. There has been less marked retreat in the central Tibetan Plateau and the Changtang Plateau (Pu et al., 2004).

Lakes supplied by glacier melting are mainly distributed in the Hoh Xil region, the Qilian Mountains, the east of the Himalayan Mountains, and the Kunlun Mountains. Glaciers in the Kunlun Mountains showed a rapid decline and since the 1970s glaciers in the east of the Kunlun Mountains decreased more than those in the west of the region (Liu et al., 2002; Shangguan et al., 2004). Glaciers in the Himalayan Mountains have decreased most rapidly. Many small glaciers have disappeared in the last 20 years (Liu et al., 2006). Glaciers in the Qilian Mountains have decreased in number, area, and storage. For example, the glaciers on Shulenan Mountain, which supplies Har Lake, retreated in the past 40 years and the rate of melting increased after the 1990s as a result of high temperatures in summer. The glaciers in the Altun Mountains showed a slight tendency to increase in area but a tendency to decrease in storage (Zhang et al., 2011c).

Glaciers in the Gangdise, Tanggula, and Karakoram Mountains also decreased in area. Glaciers in the Changtang Plateau degenerated much more slowly than those in other regions of western China (Wang et al., 2011).

Table 4 Changes in glaciers in different regions of the Tibetan Plateau

\begin{tabular}{|c|c|c|c|c|c|c|}
\hline \multirow{2}{*}{ Mts (Plateau) } & \multicolumn{3}{|c|}{ The First Chinese Glacier Inventory } & \multicolumn{3}{|c|}{ The Second Chinese Glacier Inventory } \\
\hline & Number & Area & Storage & Number & Area & Storage \\
\hline Karakoram Mountains & 3454 & 6231 & 868 & 5316 & 5988.67 & 592.86 \\
\hline Kunlun Mountains & 7694 & 12266 & 1283 & 8922 & 11524.13 & 1106.34 \\
\hline Altun Mountains & 235 & 275 & 16 & 466 & 295.11 & 15.36 \\
\hline Qilian Mountains & 2815 & 1931 & 93 & 2683 & 1597.81 & 84.48 \\
\hline Changtang Plateau & 958 & 1802 & 162 & 1162 & 1917.74 & 157.29 \\
\hline Tanggula Mountains & 1530 & 2213 & 184 & 1595 & 1843.91 & 140.34 \\
\hline Gangdise Mountains & 3538 & 1766 & 81 & 3703 & 1296.33 & 56.62 \\
\hline Nyainqêntanglha Mountains & 7080 & 10701 & 1001 & 6860 & 9559.2 & 835.3 \\
\hline Himalayan Mountains & 6475 & 8412 & 709 & 6027 & 6820.98 & 522.16 \\
\hline Sources & \multicolumn{3}{|c|}{ Liu et al., 2000} & \multicolumn{3}{|c|}{ Liu et al., 2015} \\
\hline
\end{tabular}

\subsection{Analysis of the reasons for lake changes}

In combination of data from previous studies with meteorological data, the reasons for spatial and temporal heterogeneity in lake changes can be analyzed qualitatively.

Lakes located in the Naqu region increased in area and were mainly recharged by glacier melting and precipitation. From the 1970s to 2010, annual mean precipitation increased 
rapidly in this region, which further contributed to the increase in the area of the lakes such as Siling Co and Yagen Co. The lakes located in the west of Naqu increased in area at a relatively lower rate. They were mainly recharged by runoff and precipitation. The long delivery distance from glaciers to the lakes resulted in more loss by evaporation.

The Hoh Xil region has experienced increased precipitation, higher temperatures, and a decrease in evaporation. The lakes in this region, such as Ulan Ul Lake and Hoh Xil Lake, are mainly recharged by glacier melting and runoff. Yao et al. (2013) pointed out that the lakes in this region are far from the feeding glaciers and the long delivery distance and infiltration reduced water supply to the lakes. Therefore, increasing precipitation and declining evaporation may be the main reason for the increase in area of lakes in this region.

Lakes in the Himalayan Mountains such as Yamzhog Yumco, Mapam Yum Co, and Lhanag-tso decreased in area or remained stable. In the past 40 years precipitation decreased in the west Himalayan Mountains and increased slightly in the east. Though evaporation throughout the Tibetan Plateau has decreased in the past 40 years, changes in precipitation played a more critical role in determining lake area changes. The water supply from precipitation at Yamzhog Yumco was $88.86 \%$, whereas glacier melting water and evaporation accounted for only $8.91 \%$ and $10.11 \%$, respectively, of the total supply (Li et al., 2014). Therefore, the decline in precipitation caused the decrease in area of lakes including Peiku Co, Lhanag-tso Lake, and Yamzhog Yumco Lake. Bangong Co, Mapam Yum Co, Tarong Co, and Ngangla Ringco Lake, which are mainly recharged by glacier melting and precipitation, but increased evaporation played a greater role than increased glacier melting and precipitation during the 1970 s to 2000 s. However, in the past 10 years, continued glacier melting and increased precipitation caused increases in lake area. Puma Yum Co and Yamzhog Yumco Lake are located close to each other but they showed different changes in area after the 2000s, which may be related to the impact of the Yamzhog Yumco Lake Pumped Storage Power Station (Mima et al., 2013).

Precipitation and temperature increased in the Qilian Mountains, and there was a slight increase in glacier melting between 1970 and the early 1990s. The annual mean temperature began to increase at a rapid rate in the late 1990s, accompanied by an increase in glacier melting. While evaporation increased more than precipitation, the lakes in this region still decreased in area during the 1970 s to 2000 s. In recent years, rapid glacier melting and increasing precipitation has caused an increase in area of some lakes in this region. Har Lake, recharged mainly by the glacier meltwater from Shule Mountain, decreased in area from the 1970 s to 2000 s and then increased steadily in the past 10 years. On the whole, the area of lakes in this region has remained stable as a result of increasing glacier melting (Jia et al., 2009).

Qaidam Basin is located in the northeastern Tibetan Plateau. Evaporation was much larger than precipitation in this region. The dry and warm climate caused the area of the Qinghai Lake to decrease steadily from the 1970 s to the early 2000s. Recently, as a result of increasing precipitation and increased runoff caused by rising temperatures, the lake area has begun to increase steadily.

The annual mean precipitation in the Karakoram Mountains has been decreasing and the annual mean temperature has been increasing in the past 40 years. Bangong Co is mainly recharged by runoff, and the decreased precipitation and increased temperature have led to a 
decrease in lake area (Shao et al., 2007).

The Kunlun Mountains region has a dry climate with strong evaporation. Lakes in this region underwent considerable decreases in area during the 1970s and 2000s and glaciers on the Kunlun Mountains declined markedly between the two phases of Chinese glacier inventory (Liu et al., 2000; Liu et al., 2015). The annual mean precipitation and temperature in this region increased considerably and evaporation decreased in recent years. For these reasons, the lakes in the Kunlun Mountains have increased in area since the 2000s.

\section{Discussion}

\subsection{Challenges of monitoring water balance}

There is a paucity of lake observations (e.g., lake bathymetric surveys, runoff records and climate data) over the Tibetan Plateau. This lack of data has led to inconsistent measurements of lake variations, inaccurate numerical simulations and predictions, and inadequate explanations for climate-driven mechanisms. Possible reasons for water-level changes are only given qualitatively. More research is needed to determine the contribution of different factors to water-level changes in alpine lakes.

Because of limited data, water-level changes in the medium-sized and small-sized lakes of the Tibetan Plateau are estimated on the basis of their similarities to the 35 alpine lakes investigated in the present study, although deviations are possible.

\subsection{Limitations to glacial area detection}

The permafrost has different distribution areas and types, leading to different patterns of degradation in different areas. Because of inaccessibility, complex terrain, and sparse meteorological stations, especially in the western Tibetan Plateau and at higher elevations, it is currently difficult, if not impossible, to quantify the difference between meltwater from glaciers and perennial snow cover, precipitation, and evaporation for each sub-basin or for all sub-basins. Therefore, it is not possible to directly quantify the satellite-measured lake-level increase to water budget, although the linkage between glacier melting and lake-level increase appears strong. Ongoing measurements will enrich the database for future research. Variations in regional or sub-basin glaciers and snow area and their relationship to lake-level and water-volume changes also warrant further study.

\subsection{Uncertainties in detecting lake water-level variations}

Previous studies have demonstrated that lake water-level changes determined from the ICESat/GLAS altimetry are in good agreement with those determined from in situ gauge observations (Urban et al., 2008; Zhang et al., 2011c). However, because of the limited observations from ICESat/GLAS, some intra-annual fluctuations of water level cannot be detected. Therefore, bias in water-level trends may be inevitable for limited campaigns. The limited spatial resolution of the Gravity Recovery and Climate Experiment (GRACE) prevents its application to hydrologic processes and water balance at the spatial scale in some single lake basins. To more accurately estimate the contribution of increasing lake water storage to the mass budget shown in the GRACE signals, further investigation of the relationship between 
the seasonal and inter-annual variability of the GRACE mass budget and lake water storage changes is required.

\subsection{Variable region boundaries of lake change types}

Li and Sheng (2013) analyzed the spatial heterogeneity of lake changes based on water supply and showed that increases in lake area were closely related to the distribution of glaciers. A study by Liu et al. (2002) found that the lakes supplied by glaciers increased in area whereas lakes distributed in the source regions of the Yellow River decreased in area. The sub-regions in the present paper were based on geomorphological boundaries, which reflected the imbalance in the distribution of precipitation, temperature, evaporation, and glaciers in different geomorphological regions. The lake changes showed consistency with these influencing factors and obvious spatial heterogeneity.

\section{Conclusions}

In this study, spatial and temporal heterogeneity in lake area and water level of typical alpine lakes on the Tibetan Plateau has been analyzed based on data from prior studies and long-term meteorological records.

(1) In terms of temporal changes in area, the 35 alpine lakes could be divided into five groups: rising, falling-rising, rising-falling, fluctuating, and falling. The rising-type lakes could be further divided into three subtypes: linear rising, concave exponential rising and convex logarithmic rising. The falling-rising-type lakes could also be further divided into three subtypes: gentle falling-steep rising, steep falling-steep rising, and steep falling-gentle rising. The area of the rising-falling-type lakes increased before the 1990s and decreased after the 1990s, the area of the fluctuating-type lakes showed increases and decreases, and the area of the falling-type lakes decreased in the past four decades.

(2) For spatial and temporal variation of these lakes over the past decades, they presented very different rising or falling trend, for example, Yagen Co showed the largest increase in area of $194.99 \%$. Siling Co has expanded by more than $600 \mathrm{~km}^{2}$ since the $1970 \mathrm{~s}$ and has become the largest alpine lake in Tibet. While, Lhanag-tso Lake showed a continuous linear decrease in area with an overall decrease of 4.94\%, Yamzhog Yumco Lake showed the largest decrease in area of $7.97 \%$ during the study period.

(3) In terms of spatial changes, the alpine lakes distributed in the Himalayan Mountains, Changtang Plateau, Kunlun Mountains, Qilian Mountains, Karakoram Mountains, and Qaidam Basin regions displayed various change patterns. Lakes in the Himalayan Mountains, Karakoram Mountains, and Qaidam Basin tended to decrease in area while lakes in the Naqu region and Kunlun Mountains increased in area. Lakes in the Hoh Xil region and Qilian Mountains showed increases and decreases in area.

(4) Based on ICESat altimetry data of 26 typical alpine lakes on Tibetan Plateau, 22 of them showed an upward tendency and 4 of them showed a downward tendency for water level during 2003 to 2009. The average rise in lake level during 2003 to 2009 was 0.17 $\mathrm{m} /$ year. The water-level changes in different lakes over the Tibetan Plateau also showed considerable spatial heterogeneity. Most lakes in the inner and northern part of the plateau tended to show increases in water levels, while the lakes in the Himalayan Mountains tended 
to show decreases in water levels.

(5) The changes in lake area were in accordance with regional climate change. Increasing precipitation and glacier melting were the main reasons for increases in the area of lakes in the Naqu region, Kunlun Mountains, and Karakoram Mountains. Decreased precipitation caused the lakes in the Himalayan Mountains to decrease in area. Slight increases in precipitation, the long distance from the glaciers, and increased evaporation caused the fluctuation in lake area observed in the Hoh Xil region and Qilian Mountains. The dry climate in the Qaidam Basin since the 1970s caused decreases in lake area, but as the climate turned from dry to wet in the past 10 years, the lakes in this area showed a tendency to increase in area.

\section{References}

Aizen V, Aizen E, Melack J, 1996. Precipitation, melt and runoff in the northern Tien Shan. Journal of Hydrology, 186: $229-251$.

Aizen V, Kuzmichenok V, Surazakov A et al., 2007. Glacier changes in the Tien Shan as determined from topographic and remotely sensed data. Global and Planetary Change, 56: 328-340.

Angel J, Kunkel K, 2010. The response of Great Lakes water levels to future climate scenarios with an emphasis on Lake Michigan-Huron. Journal of Great Lakes Research, 36: 51-58.

Bai J, Chen X, Li J et al., 2011. Changes of inland lake area in arid Central Asia during 1975-2007: A remote-sensing analysis. Journal of Lake Sciences, 23(1): 80-88. (in Chinese)

Bian D, Bian B, La B et al., 2010. The Response of water level of Selin Co to climate change during 1975-2008. Acta Geographica Sinica, 65(3): 313-319. (in Chinese)

Bian D, Du J, Hu J et al., 2009. Response of the water level of the Yamzho Yumco to climate change during 1975-2006. Journal of Glaciology and Geocryology, 31(3): 404-409. (in Chinese)

Bolch T, 2007. Climate change and glacier retreat in northern Tien Shan (Kazakhstan/Kyrgyzstan) using remote sensing data. Global and Planetary Change, 56: 1-12.

Bolch T, Menounos B, Wheate R, 2010. Landsat-based inventory of glaciers in western Canada, 1985-2005. Remote Sensing of Environment, 114: 127-137.

Chen F, Kang S, Zhang Y et al., 2009. Glaciers and lake change in response to climate change in the Nam Co basin, Tibet. Journal of Mountain Science, 27(6): 641-647. (in Chinese)

Chipman J, Lillesand T, 2007. Satellite based assessment of the dynamics of new lakes in Southern Egypt. International Journal of Remote Sensing, 28: 4365-4379.

Chu D, Pu Q, Wang D et al., 2012. Water level variations of Yamzho Yumco Lake in Tibet and the main driving forces. Journal of Mountain Science, 30(2): 239-247. (in Chinese)

Deji Y, La B, Laba Z et al., 2014. Lake area variation of Thari Namtso and its meteorological causes based on multi-sensor satellite data. Journal of Lake Sciences, 26(6): 963-970. (in Chinese)

Ding Y, Liu S, Ye B et al., 2006. Climatic implications on variations of lakes in the cold and arid regions of China during the recent 50 years. Journal of Glaciology and Geocryology, 28(5): 623-632. (in Chinese)

Donald O, Thomas C, 1997. Dynamics of water-table fluctuations in an upland between two prairie-pothole wetlands in North Dakota. Journal of Hydrology, 191: 266-289.

Du J. 2001. Change of temperature in Tibetan Plateau from 1961-2000. Acta Geographica Sinica 56(6): 690-698. (in Chinese)

Fan Z, Li J, 1984. Recent changes in the lakes of Xinjiang. Geographical Research, 3(1): 77-86. (in Chinese)

Gao H, Jia Y, 2005. The evolution characteristics of typical inland lakes in Northwest China during the past 40 years and their mechanism. Journal of Arid Land Resources and Environment, 19(5): 93-96. (in Chinese)

Guo L, Ye Q, Yao T et al., 2007. The glacial landforms and the changes of glacier and lake area in the Mapam Yumco Basin in Tibetan Plateau based on GIS. Journal of Glaciology and Geocryology, 29(4): 517-524. (in 


\section{Chinese)}

Guo N, Zhang J, Liang Y, 2003. Climate change indicated by the recent change of inland lakes in northwest China. Journal of Glaciology and Geocryology, 25(2): 211-214. (in Chinese)

$\mathrm{Hu}$ R, Jiang F, Wang Y et al., 2007. On the importance of research on the lakes in arid land of China. Arid Zone Research, 24(2): 137-140. (in Chinese)

$\mathrm{Hu} \mathrm{R}, \mathrm{Ma} \mathrm{H}$, Fan Z et al., 2002. The climate trend demonstrated by changes of the lakes in Xinjiang since recent years. Journal of Arid Land Resources and Environment, 16(1): 20-27. (in Chinese)

Huang W, Liao J, Shen G et al., 2012. Lake change in past 40 years in the Southern Nagqu District of Tibet and analysis of its driving forces. Remote Sensing for Land and Resources, 94: 122-128. (in Chinese)

Jia W, He Y, Wang X et al., 2009. Temporal and spatial change of the potential evaporation over Qilian Mountains and Hexi corridor from 1960 to 2006. Advances in Water Science, 20(2): 159-167. (in Chinese)

Jiang L, Yao Z, Liu Z et al., 2014. Variations of lake area and boundary of Ulan U1 Lake in Hoh Xil region during 1976-2012 and their reasons. Wetland Science, 12(2): 155-162. (in Chinese)

Jones R, McMahon T, Bowler J, 2001. Modelling historical lake levels and recent climate change at three closed lakes, Western Victoria, Australia (c.1840-1990). Journal of Hydrology, 246: 159-180.

Kong Y, Pang Z, 2012. Evaluating the sensitivity of glacier rivers to climate change based on hydrograph separation of discharge. Journal of Hydrology, 434/435: 121-129.

Krause P, Biskop S, Helmschrot J et al., 2010. Hydrological system analysis and modelling of the Nam Co Basin in Tibet. Advances in Geosciences, 27: 29-36.

Kropáček J, Brauna A, Kang S et al., 2012. Analysis of lake level changes in Nam Co in central Tibet utilizing synergistic satellite altimetry and optical imagery. International Journal of Applied Earth Observation and Geoinformation, 17: 3-11.

Kutuzov S, Shahgedanova M, 2009. Glacier retreat and climatic variability in the eastern Terskey-Alatoo, inner Tien Shan between the middle of the 19 th century and beginning of the 21 st century. Global and Planetary Change, 69: 59-70.

La B, Bian D, Chen T et al., 2012. Possible causes of area change of lake Tangra Yumco, Tibet based on TM images. Meteorological Science and Technology, 40(4): 685-688.

La B, La B, Chen T, 2011. Change research and cause analysis of inland lakes in Tibet based on MODIS image. Meteorological and Environmental Sciences, 34(3): 37-40. (in Chinese)

Lei Y, Zhang H, Wang S et al., 2009. Change in Lake Area of Zige Tangco on central Tibetan Plateau since the 1970s and its mechanisms. Journal of Glaciology and Geocryology, 31(1): 48-54. (in Chinese)

Li B, Pan B, Cheng W et al., 2013. Research on geomorphological regionalization of China. Acta Geographica Sinica, 68(3): 291-306. (in Chinese)

Li J, Fang H, Bao A et al., 2011. Spatio-temporal analysis of recent changes of lake area and lake water level at high mountains in Central Asia. Resources Science, 33(10): 1839-1846. (in Chinese)

Li J, Sheng Y, 2013. Spatiotemporal pattern and process of inland lake change in the Qinghai-Tibetan Plateau during the period of 1976-2009. Arid Zone Research, 30(4): 571-581. (in Chinese)

Li L, Li J, Yao X et al., 2014. Changes of the three holy lakes in recent years and quantitative analysis of the influencing factors. Quaternary International, 349: 339-345.

Li Z, 2014. Glacier and lake changes across the Tibetan Plateau during the past 50 years of climate change. Journal of Resources and Ecology, 5(2): 123-131.

Liao J, Shen G, Li Y, 2013. Lake variations in response to climate change in the Tibetan Plateau in the past 40 years. International Journal of Digital Earth, 6(6): 534-549.

Liu C, Shi Y, Wang Z et al., 2000. Glacier resources and their distributive characteristics in China. Journal of Glaciology and Geocryology, 22(2): 106-112. (in Chinese)

Liu J, Wang S, Yu S et al., 2009. Climate warming and growth of high-elevation inland lakes on the Tibetan Plateau. Global and Planetary Change, 67: 209-217.

Liu R, Liu Y, 2008. Area changes of Qinghai Lake in the latest 20 years based on remote sensing study. Journal of Lake Sciences, 20(1): 135-138. (in Chinese) 
Liu S, Ding Y, Li J et al., 2006. Glaciers in response to recent climate warming in western China. Quaternary Sciences, 26(5): 762-771.

Liu S, Lu A, Ding Y et al., 2002. Glacier fluctuations and the inferred climate changes in the Nyainqêntanglha Mountains in the source area of the Yellow River. Journal of Glaciology and Geocryology, 24(6): 701-707. (in Chinese)

Liu S, Yao X, Guo W et al., 2015. The contemporary glaciers in China based on the Second Chinese Glacier Inventory. Acta Geographica Sinica, 70(1): 3-16. (in Chinese)

Liu T. 1995. Changes of Yamzho Lake water stage in Xizang. Scientia Geographica Sinica, 15(1): 55-62. (in Chinese)

Ma D, Zhang L, Wang Q et al., 2003. Influence of the warm-wet climate on Sayram Lake. Journal of Glaciology and Geocryology, 25(2): 219-223. (in Chinese)

Ma R, Yang G, Duan H et al., 2010. China's lakes at present: Number, area and spatial distribution. Science China Earth Sciences, 54(2): 283-289.

Ma Y, Yi C, Wu J et al., 2012. Lake surface expansion of Nam Co during 1970-2009: Evidence of satellite remote sensing and cause analysis. Journal of Glaciology and Geocryology, 34(1): 81-88. (in Chinese)

Meng K, Shi X, Wang E et al., 2012. High-altitude salt lake elevation changes and glacial ablation in Central Tibet, 2000-2010. Chinese Science Bulletin, 57(5): 525-534.

Mercier F, Cazenave A, Maheu C, 2002. Interannual lake level fluctuations (1993-1999) in Africa from Topex/Poseidon: Connections with ocean-atmosphere interactions over the Indian Ocean. Global and Planetary Change, 32: 141-163.

Mima C, Tian L, Wen R et al., 2013. Recent water level change of Yamzhog Yumco Lake, Tibet. Journal of China Hydrology, 33(2): 64-69. (in Chinese)

Niu T, Chen L, Zhou Z, 2004. The characteristics of climate change over the Tibetan Plateau in the last 40 years and the detection of climatic jumps. Advances in Atmospheric Sciences, 21(2): 193-203.

Niu Y, Li C, Xi X et al., 2008. Plateau lake variation monitored by satellite remote sensing and the relation to climate change. Arid Land Geography, 31(2): 284-290. (in Chinese)

Phan V H, Lindenbergh R, Menenti M, 2012. ICESat derived elevation changes of Tibetan lakes between 2003 and 2009. International Journal of Applied Earth Observation and Geoinformation, 17: 12-22.

Ponchaut F, Cazenave A, 1998. Continental lake level variations from Topex/Poseidon (1993-1996). Comptes Rendus de l'Académie des Sciences-Series IIA-Earth and Planetary Science, 326: 13-20.

$\mathrm{Pu}$ J, Yao T, Wang N et al., 2004. Fluctuations of the glaciers on the Qinghai-Tibetan Plateau during the past century. Journal of Glaciology and Geocryology, 26(5): 517-522. (in Chinese)

Qi W, Zheng M, 2006. Initial research on water level fluctuation discipline of Zabuye Salt Lake in Tibet. Scientia Geographica Sinica, 26(6): 693-701. (in Chinese)

Qiao C, Luo J, Sheng Y et al., 2010. Analysis on lake changes since ancient and modern ages using remote sensing in Dagze Co, Tibetan Plateau. Journal of Lake Sciences, 22(1): 98-102. (in Chinese)

Qin B, 1999. A preliminary investigation of lake evolution in 20-century in inland mainland Asia with relation to the global warming. Journal of Lake Sciences, 11(1): 11-19. (in Chinese)

Shangguan D, Liu S, Ding Y et al., 2004. Glacier changes at the head of Yurungkax River in the west Kunlun Mountains in the past 32 years. Acta Geographica Sinica, 59(6): 855-862.

Shao Z, Zhu D, Meng X et al., 2007. Characteristics of the change of major lakes on the Qinghai-Tibet Plateau in the last 25 years. Geological Bulletin of China, 26(12): 1633-1645. (in Chinese)

Shi Y, Shen Y, Kang E et al., 2007. Recent and future climate change in Northwest China. Climatic Change, 80(3): 379-393.

Shi Y, Zhang X, 1995. The effect of climate change on surface water resources and future trend in the northwest arid region, China. Science in China (Series B), 25(9): 968-977. (in Chinese)

Song C, Huang B, Ke L, 2013. Modeling and analysis of lake water storage changes on the Tibetan Plateau using multi-mission satellite data. Remote Sensing of Environment, 135: 25-35.

Song C, Ye Q, Cheng X, 2015. Shifts in water-level variation of Namco in the central Tibetan Plateau from ICE- 
Sat and CryoSat-2 altimetry and station observations. Science Bulletin, 60(14): 1287-1297.

Sorg A, Bolch T, Stoff M et al., 2012. Climate change impacts on glaciers and runoff in Tien Shan (Central Asia). Nature Climate Change, 29: 1-7.

Tang W, Yang K, Qin J et al., 2011. Solar radiation trend across China in recent decades: A revisit with quality-controlled data. Atmospheric Chemistry and Physics, 11: 393-406.

Urban T, Schutz B, Neuenschwander A, 2008. A survey of ICESat coastal altimetry applications: Continental coast, open ocean island, and inland river. Terrestrial, Atmospheric and Oceanic Sciences, 19(1): 1-19.

Wan W, Xiao P, Feng X et al., 2014. Monitoring lake changes of Qinghai-Tibet Plateau over the past 30 years using satellite remote sensing data. Chinese Science Bulletin, 59(8): 701-714. (in Chinese)

Wang B, Bao Q, Hoskins B et al., 2008. Tibetan Plateau warming and precipitation changes in East Asia. Geophysical Research Letters, 35(14): L14702, 1-5.

Wang L, Xie Z, Liu S et al., 2011. Glacierized area variation and its response to climate change in Qangtang Plateau during 1970-2000. Journal of Glaciology and Geocryology, 33(5): 979-990. (in Chinese)

Wang X, Gong P, Zhao Y et al., 2013. Water-level changes in China's large lakes determined from ICESat/GLAS data. Remote Sensing of Environment, 132: 131-144.

Wu Y, Zhu L, Ye Q et al., 2007. The response of lake-glacier area change to climate variations in Nam Co Basin, central Tibetan Plateau, during the last three decades. Acta Geographica Sinica, 62(3): 301-311. (in Chinese)

Yan L, Zheng M, 2015. The response of lake variations to climate change in the past forty years: A case study of the northeastern Tibetan Plateau and adjacent areas, China. Quaternary International, 371: 31-48.

Yan Q, Liao J, Shen G, 2014. Remote sensing analysis and simulation of change of Ulan U1 Lake in the past 40 years. Remote Sensing for Land and Resources, 26(1): 152-157. (in Chinese)

Yao X, Liu S, Li L et al., 2013. Spatial-temporal variations of lake area in Hoh Xil region in the past 40 years. Acta Geographica Sinica, 68(7): 886-896. (in Chinese)

Ye Q, Yao T, Zheng H et al., 2008. Glacier and lake co-variations and their responses to climate changes in the Mapam Yumco Basin on Tibet. Geographical Research, 27(5): 1178-1190. (in Chinese)

You Q, Kang S, Pepin N et al., 2010. Climate warming and associated changes in atmospheric circulation in the eastern and central Tibetan Plateau from a homogenized dataset. Global and Planetary Change, 72(1/2): 11-24.

Zhang G, Xie H, Duan S et al., 2011a. Water level variation of Lake Qinghai from satellite and in situ measurements under climate change. Journal of Applied Remote Sensing, 5: 053532-1-053532-15.

Zhang G, Xie H, Kang S et al., 2011b. Monitoring lake level changes on the Tibetan Plateau using ICESat altimetry data (2003-2009). Remote Sensing of Environment, 115: 1733-1742.

Zhang G, Xie H, Yao T et al., 2014a. Quantitative water resources assessment of Qinghai Lake Basin using snowmelt runoff model (SRM). Journal of Hydrology, 519: 976-987.

Zhang H, Lu A, Wang L et al., 2011c. Glacier change in the Shulenan Mountain monitored by remote sensing. Journal of Glaciology and Geocryology, 33(1): 8-12.

Zhang X, Ren Y, Yin Z et al., 2009. Spatial and temporal variation patterns of reference evapotranspiration across the Qinghai-Tibetan Plateau during 1971-2004. Journal of Geophysical Research, 114: D15105.

Zhang X, Wu Y, Zhang X, 2014b. Water level variation of inland lakes on the south-central Tibetan Plateau in 1972-2012. Acta Geographica Sinica, 69(7): 993-1001. (in Chinese)

Zhang Y, Liu C, Tang Y et al., 2007. Trends in pan evaporation and reference and actual evapotranspiration across the Tibetan Plateau. Journal of Geophysical Research, 112, D12110.

Zhao Y. 2014. Dynamic variations of glaciers-lake in YamzhoYumco Basin of Tibet. Journal of Arid Land $R$ esources and Environment, 28(8): 88-93. (in Chinese)

Zhu L, Xie M, Wu Y, 2010. Quantitative analysis of lake area variations and the influence factors from 1971 to 2004 in the Nam Co Basin of the Tibetan Plateau. Chinese Science Bulletin, 55(18): 1294-1303. (in Chinese) 